\title{
Gold standard for nutrition: a review of human milk oligosaccharide and its effects on infant gut microbiota
}

\author{
Shunhao Zhang ${ }^{1 \#}$, Tianle $\mathrm{Li}^{1 \#}$, Jing Xie ${ }^{1}$, Demao Zhang ${ }^{1}$, Caixia $\mathrm{Pi}^{1}$, Lingyun Zhou ${ }^{2^{*}}$ and Wenbin Yang ${ }^{3^{*}}$ (0)
}

\begin{abstract}
Human milk is the gold standard for nutrition of infant growth, whose nutritional value is mainly attributed to human milk oligosaccharides (HMOs). HMOs, the third most abundant component of human milk after lactose and lipids, are complex sugars with unique structural diversity which are indigestible by the infant. Acting as prebiotics, multiple beneficial functions of $\mathrm{HMO}$ are believed to be exerted through interactions with the gut microbiota either directly or indirectly, such as supporting beneficial bacteria growth, anti-pathogenic effects, and modulation of intestinal epithelial cell response. Recent studies have highlighted that HMOs can boost infants health and reduce disease risk, revealing potential of HMOs in food additive and therapeutics. The present paper discusses recent research in respect to the impact of $\mathrm{HMO}$ on the infant gut microbiome, with emphasis on the molecular basis of mechanism underlying beneficial effects of HMOs.
\end{abstract}

Keywords: Human milk, Human milk oligosaccharides (HMOs), Oligosaccharides (OS), Infant gut microbiota, Bifidobacterium, Prebiotics, Infant formula

\section{Background}

It is widely acknowledged that breastfeeding is not only an evolutionary optimized means for feeding babies since ancient time but also the gold standard for infant nutrition, and World Health Organization (WHO) stipulates that mother should exclusively breastfeed her infant for the first 6 months since birth [1-3]. On the one hand, breastfeeding offer infants nutrients needed for healthy development and growth [4,5]; on the other hand, breastfeeding also provide infants with protection against

\footnotetext{
*Correspondence: lingyunzhou@scu.edu.cn; yangwenbin@scu.edu.cn

"Shunhao Zhang and Tianle Li contributed equally to this work.

${ }^{2}$ Center of Infectious Diseases, West China Hospital of Sichuan University,

No. 37 Guoxue Alley, Wuhou District, Chengdu 610041, China

${ }^{3}$ State Key Laboratory of Oral Diseases, National Clinical Research

Center for Oral Diseases, Department of Oral and Maxillofacial Surgery,

Department of Medical Affairs, West China Hospital of Stomatology,

Sichuan University, No. 14, Section 3, South Renmin Road,

Chengdu 610041, Sichuan, China

Full list of author information is available at the end of the article
}

gastrointestinal and respiratory infections, and a reduced incidence of various diseases, such as obesity, diabetes, atopy, and asthma [6-12]. Besides, breastfeeding is beneficial to both babies and their mothers [13]. With recent advances and development in analytical tools for structural characterisation, scientists are engaged in the process of identifying the composition of human milk, which is featured by abundant and diverse human milk oligosaccharides (HMOs) [14]. Back to the end of the nineteenth century, the phenomenon that bottlefed infants had a much lower survival rate and a higher chance of infection in comparison to breastfed infants, aroused the scientific interest in the composition of human milk whose positive effects benefit infant health in early life. In 1900, differences in the bacteria composition between breastfed and non-breastfed infant feces were noted, and bifidobacteria seemed to enrich in breastfed infant stool [15]. With another 50-plus years efforts on HMO research, the bifidogenic factor in human milk was identified as 
oligosaccharides (OS) containing polysaccharides and $\mathrm{N}$-acetylglucosamine (GlcNAc) [16-18]. Nowadays, more than 200 HMOs have been identified and many beneficial effects of human milk attribute to HMOs that are believed to be exerted through interactions with the gut microbiota [19]. Among components of human milk, lactose and lipids are the main source of energy to the infants which provide the uppermost source of carbohydrates at the average concentration of 30-70 g/L [20-22]. Compared with lactose and lipids, HMOs are the third largest solid component of human milk which are only slightly hydrolyzed and eventually accumulate in infant gastric intestinal tract. HMOs are complex carbohydrates and known to function as prebiotic serving as substrates for certain gut microbes in the colon tract due to their indigestible property to the infant $[23,24]$. Though well regulated, the development of a healthy host-microbe symbiosis in the newborn gastrointestinal tract, which is an extremely complex and crucial biological process, is still a highly vulnerable period $[25,26]$. Breastfed infants are featured by abundant bifidobacteria in gut microbiota, which is considered safe and beneficial to infants [27]. Besides, HMOs are increasingly linked to protection against causative organisms, such as pathogenic bacterium, virus, protozoan parasite, and fungus.

This review presents current advances in respect to the impact of HMO on the infant gut microbiome, and the critical insight into the beneficial effects of HMOs and the mechanism behind them.

\section{HMOs}

\section{Chemical structure of HMOs}

$\mathrm{HMO}$ is a collective terms referring to a group of various OS which is present in human milk and they are made up of five basic units including one acid monosaccharide, namely sialic acid (Sia) or N-acetylneuraminic acid; one amino sugar which is known as GlcNAc; three monosaccharides which are L-fucose (Fuc), D-galactose (Gal), and D-glucose (Glc) [28]. Although the combination of these five building blocks in diverse directions and sequences is immense, only approximately 200 different HMOs have been characterized so far and 50 compositions of HMOs are assumed to represent $99 \%$ of HMO abundance in human mother's milk $[19,24]$. All HMOs contain a lactose core $(\mathrm{Gal} \beta-1,4 \mathrm{Glc})$ at the reducing end [29], which can be further lengthened enzymatically by $\beta 1-3$ or $\beta 1-6$ linkage to either Gal $\beta 1-3 \mathrm{GlcNAc}$ (lacto- $N$-biose, LNB, type-1 chain) or to Gal $\beta 1-4$ GlcNAc ( $N$-acetyllactosamine, type- 2 chain) [30]. Besides, the core HMO structures can also be decorated by Sia via $\alpha 2-3$ or $\alpha 2-6$ linkages and/or Fuc via $\alpha 1-2, \alpha 1-3$, or $\alpha 1-4$ linkages at the terminal positions [30]. Therefore, HMO can be mainly classified into three groups: fucosylated OS (FucOS), sialylated OS (SiaOS), and neutral OS (Fig. 1).

\section{Concentration of HMOs in human milk}

Human milk is regarded as the golden standard for newborn babies [20] thanks to its variable composition of nutrients which contributes to the protection against pathogenic bacteria or viruses [31], prevention against bowel inflammation, and constructive modulation of the immune system response during the development of infants [32,33]. Although composition of human milk varies from person to person, HMOs are the main nutrients benefitting newborns' growth. HMOs are abundantly present in human milk representing about $20 \%$ of all carbohydrate in colostrum $[34,35]$. The stage of lactation determines HMOs amount in human milk which varies from $20-24 \mathrm{~g} / \mathrm{L}$ in the earliest human milk to10$15 \mathrm{~g} / \mathrm{L}$ in mature milk on average [20,34-36]. On the one hand, the concentration and relative abundance of non FucOS and SiaOS declined with time, but on the other hand, the relative abundance of FucOS increased despite their decreased concentration [35]. In comparison to the amount of OS in cow's milk (up to $1 \mathrm{~g} / \mathrm{L}$ in the earliest milk and $0.05-0.1 \mathrm{~g} / \mathrm{L}$ in mature milk which remarkably depends on inter-breed and seasonal difference), we can find that human milk has up to 22-26 times higher levels and a higher variety of OS, indicating that the composition and structure of HMOs may be far more complicated than OS in cow's milk [37-39].

\section{Endogenous synthesis of HMOs}

The polymorphism of several genes contributes to wide variability of HMOs during the endogenous synthesis process. When it comes to biosynthesis of FucOS, Secretor (Se) gene and Lewis (Le) gene play important roles in encoding different fucosyltransferases to determine both the quantitative and qualitative composition of HMOs [34]. Activation of the Se gene leads to the expression of $\alpha 1$-2-fucosyltransferase enzyme (FUT2) who is responsible for lengthening the terminal Gal of the type- 1 chain of HMOs by Fuc via $\alpha 1-2$ linkage [40, 41]. The Le gene allows the expression of $\alpha 1-3 / 4$-fucosyltransferase (FUT3) to add Fuc with $\alpha 1-3 / 4$ linkage to a subterminal GlcNAc of the type-1 chain of HMOs [42, 43]. According to the different expression of both Se gene and Le gene, mothers can be classified as either positive $(+)$ or negative $(-)$ for both genes and divided into four different groups (Fig. 2): $\mathrm{Se}(+) \mathrm{Le}(+), \mathrm{Se}(-) \mathrm{Le}(+), \mathrm{Se}(+) \mathrm{Le}(-)$, and $\mathrm{Se}(-) \mathrm{Le}(-)[41,44]$, where $70 \%$ are $\mathrm{Se}(+) \mathrm{Le}(+), 20 \%$ $\mathrm{Se}(-) \mathrm{Le}(+), 9 \% \mathrm{Se}(+) \mathrm{Le}(-)$, and $1 \% \mathrm{Se}(-) \mathrm{Le}(-)[36,45-$ 47]. For females who belong to the $\mathrm{Se}(+) \mathrm{Le}(+)$ genotype and therefore have functional FUT2 and FUT3 enzymes, 




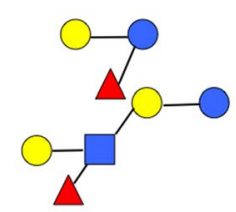

LNFP III LNFP V 3-FL

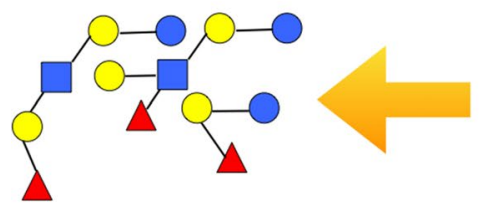

LNFPI LNFP III 2'-FL 3-FL

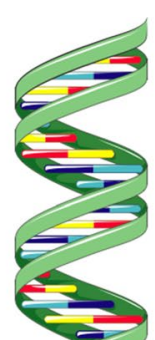

$\mathrm{Se}(+) \mathrm{Le}(+)$
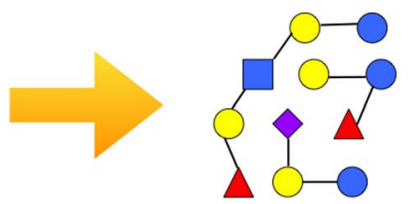

All FucOs

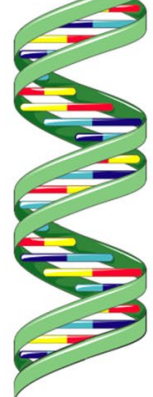

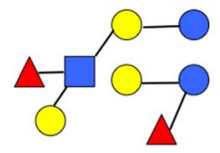

LNFP II LNFP III 3-FL

Fig. 2 Four phenotypes of FucOS were produced by Se and Le genes $[41,44]$. Se and Le genes play an important role in determining the composition of FucOS [34]. FUT2 is encoded by the first gene whereas FUT3 is encoded by the second one [40-43]. According to the activation state of genes, mothers can be classified as either positive (+) or negative (-) for both genes, where $70 \%$ are $\mathrm{Se}(+) \mathrm{Le}(+), 20 \% \mathrm{Se}(-) \mathrm{Le}(+), 9 \% \mathrm{Se}(+)$ Le(-), and 1\% Se(-)Le(-) [36, 45-47], and phenotypes to production of FucOS and main FucOS synthesized are showed 
all types of FucOS can be found in their milk. The $\mathrm{Se}(-)$ $\mathrm{Le}(+)$ women produce milk containing FucOS with $\alpha 1,3$ and $\alpha 1,4$ linkages such as lacto- $\mathrm{N}$-fucopentaose (LNFP) II, LNFP III, and 3-fucosyllactose (FL). Mothers with the $\mathrm{Se}(+) \mathrm{Le}(-)$ genotype can synthesize LNFP I, LNFP III, $2^{\prime}$-FL, and 3-FL. Those identified as $\mathrm{Se}(-) \mathrm{Le}(-)$ are capable of producing FucOS with $\alpha 1,3$ bonds such as LNFP III, LNFP V, and 3-FL. However, under some circumstances the biosynthesis of FusOS cannot be perfectly elucidated by the expression of Se and Le genes, implying that there might be an unknown FUT taking part in this process or an unidentified synthetic pathway independent from FUT [19, 44, 48-51].

As for biosynthesis of SiaOS, two genes namely Le and $\mathrm{ABH}$ are implicated in this process. Low levels of SiaOS are observed in the milk of mothers with the $\mathrm{ABH}(-)$ $\mathrm{Le}(-)$ genotype, while those representing the $\mathrm{ABH}(+)$ $\mathrm{Le}(+)$ genotype can express high levels of SiaOS such as disialyllacto- $N$-tetraose (DSLNT), LS-tetrasaccharide (LSTa), 3'-sialyllactose (SL), and 6'-SL [52-54].

Moreover, biosynthesis of core OS contributes to increased variability of HMO structures in human milk. There are four glycosyltransferases activated in this course: $\beta 3$-galactosyltransferases and $\beta 4$ galactosyltransferases are responsible for Gal relocation, while $\beta 1,3-N$-acetylglucosaminyltransferase (iGnT) and $\beta 1,6-N$-acetylglucosaminyltransferase (IGnT) are involved in the GlcNAc transfer $[55,56]$.

Of note, besides various genes participating in HMOs biosynthesis, it is believed that there are other factors also influence endogenous synthesis of HMO. Though total HMO concentration decreased substantially over the course of lactation [35], a more significant decrease in HMO would occur in the effect of the seasonal changes and certain nutritional conditions of the mother. In Gambia, lactating mothers who nursed their children during the wet season produce milk with lower HMO concentration in comparison to those nursing in the dry season when the food is more plentiful and energy intake is higher [57]. Besides, a Canadian study suggests that other seasonal factors such as climate, sunlight, and allergen exposures might influence HMO synthesis in Canadian population [45]. Similarly, the HMO composition in breast milk may be changed when mothers are supplemented with a mixture of probiotics during late stages of pregnancy. Seppo et al. showed that the concentrations of 3-FL and 3'-SL were significantly higher in the colostrum of mothers who received probiotic supplementation than in control participants; however, the total concentration of HMOs still decreased in colostrum from the mothers in the probiotic supplementation group due to the lower levels of difucosyllacto- $N$-hexaose, lacto- $N$-tetraose (LNT), LNFP I, and 6'-SL [58]. Another study also indicated the positive association between SiaOS concentration and vitamin A intake [59], while a lipid-based nutrient supplement showed no effect on HMO concentration [60]. When it comes to the effect of maternal age, weight, body mass index, and parity on the endogenous synthesis of HMO, there is a contradiction between different studies [45, 47, 57, 61]. In brief, studies mentioned above all suggest that wide variability of HMOs due to the genes polymorphism and environmental condition may have different effects on gut microbiota development, infant health, and disease risk.

\section{Metabolism of HMOs}

HMOs are resistant against an infant's digestive enzymes and can remain their special structural configuration through the proximal intestine, which has been affirmed by several clinical studies [54, 62-64]. Then they would reach the distal intestine serving as a substrate fermented by specific intestinal microbiota, such as Firmicutes, Proteobacteria, and especially Bifidobacterium spp. [39, 63, 65-67]. In particular, HMOs degradation mediated by Bifidobacterium spp. can be divided into two strategies. The first approach is initialed by the importation of complete HMOs into the cytoplasm through adenosine triphosphate binding cassette $(\mathrm{ABC})$ transporter, which will be hydrolyzed by intracellular glycosidases, while the other one depends on cell wall-anchored secretory glycosyl hydrolases (GHs), which hydrolyze HMOs and release monosaccharides and disaccharides $[68,69]$. For example, $B$. bifidum uses extracellular hydrolases releasing LNB which is the core structure of type-1 HMO, while $B$. infantis and $B$. breve use oligosaccharide transporters [70]. However, the HMOs degradation pattern of $B$. longum depends on strains and the existence of lactamN-biogenase (LnbX). LnbX-negative B. longum utilizes oligosaccharide transporters to assimilate HMO derivatives internally, whereas LnbX-positive B. longum utilizes extracellular hydrolases [71]. Furthermore, depending on the consumption of certain HMOs, some microbes that are capable of catabolizing HMOs will obtain predomination over others [72,73], which function as a probiotic shaping the infant's intestinal microbiota [74, 75]. For instance, the predominant presence of intestinal bacteria from Bifidobacterium spp. has been related to human milk with a higher content of sialyllacto- $N$-tetraose b (LSTb), monofucosyllacto-N-hexaose (MFLNH)- III, DSLNT, LNFP I, LNFP III, and LNFP V; whereas 2'-FL, lacto-N-hexaose (LNH) and two of its isomers found in human milk benefited the growth of Bacteroides spp. [63, $66,76]$.

After ingested, about 99\% of HMO reach the intestine and nearly $45 \%$ of them are fermented by intestinal microbiota, while $1-4 \%$ and $40-50 \%$ of total HMOs 
ingested are excreted in the urine and feces, respectively $[54,62]$. The remaining $1 \%$ are absorbed at concentrations of $0.10-0.20 \mathrm{~g} / \mathrm{L}$, resulting in plasma concentration of $0.01-0.10 \mathrm{mg} / \mathrm{L}$ [20, 77, 78]. According to Goehring et al. [54] and Vazquez et al. [78], $2^{\prime}$-FL and lacto- $N$-neotetraose (LNnT), which are smaller molecular weight HMOs, are absorbed quickly into bloodstream and excreted in the urine without metabolism, suggesting that certain HMOs in urine may reflect the mother's secretor/ nonsecretor status, whereas HMOs with fecal excretion varies remarkably correlating with infant's different intestinal microbiota [62]. Notably, some novel HMOs that not related to common HMOs are found in infant's urine and feces due to microbial metabolism [62], showing differences in the metabolism patterns of HMOs. Furthermore, in contrast to traditional cognition that the infant has contact with mother's HMOs through postnatal feeding, recent studies revealed that the fetus might have been already exposed to HMOs in utero given the presence of HMOs in mothers body fluid during pregnancy and in amniotic fluid at delivery $[79,80]$.

\section{Microbiota}

HMOs once ingested begin to interact with various microbes including bacteria, viruses, protozoan parasites, and fungi inside the infant body leading to a series of constructive effects indirectly [81]. Therefore, a better understanding of neonate microbiota will definitely advance our insight into the positive role of HMOs.

After the process of giving birth, bacteria colonize in the relatively sterile gastrointestinal tract of the newborn rapidly, which marks the beginning of the highly complex formation of the microbiota [82, 83]. Therefore, the first year of newborn's life is crucial for the establishment of the intestinal microbiome, which underlies the folate production, reduction of allergic diseases, increased immune responses to vaccinations, synthesis of essential vitamins and other molecules that serve as modulators of physiological responses and are used as energy source by the intestinal epithelium [84-89]. The earliest gut microbiome is characterized by the colonization of facultative anaerobes, such as streptococci, enterococci, and staphylococci [82]. As the main component of infant diet, the wide presence of HMO in human milk act as one of the most vital factors shaping the latter gut microbiome that represented by Bacteroides spp., Clostridium spp., and especially Bifidobacterium spp. with up to $90 \%$ of total microbes within the first 3 months of the baby's life [90, 91].

Bifidobacteria are gram-positive and heterofermentative obligate anaerobes which are among the first bacteria to inhabit human digestive tracts [92], with 78 species and 10 subspecies classified to date [93-96]. About ten (sub)species were isolated from human feces and certain species seem to be frequently found in the infant gut, such as $B$. breve and $B$. infantis [97-100], while other species, such as $B$. longum, $B$. pseudocatenulatum, and $B$. bifidum are likely to inhabit both in the infant and adult gut microbiome [101, 102]. Besides, Bifidobacterium spp. remain the dominant bacteria in infant gut microbiota during breast-feeding, yet the relative abundances quickly decline after weaning $[98,103]$, during when the compositional change takes place at species level [104], indicating the direct correlation between HMOs and developing infant microbiota. According to several studies, a significant decline in fecal HMOs was positively correlated with high levels of HMO-consuming bifidobacteria [76, 97]; furthermore, a specific $\beta$-galactosidase from $B$. longum was applied to catabolize HMOs in vitro, whose catabolized fragments were found to match with compounds identified in infant fecal samples [105]. Subsequent studies focus on the consumption of HMOs by Bifidobacterium spp. As Ward et al. reported, B. infantis ATCC 15697 was observed to use HMOs as a sole carbon source [106], and studies conducted by Garrido et al. showed a similar result that isolates of $B$. infantis grew well on pooled HMOs and individual HMO sugars while some examined strains of $B$. bifidum could not grow with $2^{\prime}$-FL and $6^{\prime}$-SL as a sole carbon source [68]. Notably, while HMOs are mainly consumed by bifidobacteria, it is undoubted that certain isolates of bifidobacteria have stronger capability to ferment HMOs, meanwhile, some types of HMO are more frequently assimilated by bifidobacteria than others. Therefore, accumulating studies have tried to figure out the mechanisms of how bifidobacteria catabolize HMOs and revealed that the consumption of HMO is well conserved among $B$. infantis strains, fermenting all classes of HMO [68, 107, 108]. Take $B$. infantis ATCC 15697 for example, this strain of $B$. infantis can utilize several types of HMO including sialylated and fucosylated molecules [108]. The genome sequence of B. infantis ATCC 15697 showed a great number of HMO-utilization genes located in a specific segment of the genome, namely HMO cluster I [109], whose expression led to up-regulation of GHs [110] and family 1 solute binding proteins (SBPs) that is a part of $\mathrm{ABC}$ transporters for HMOs [111]. The process of HMO consumption begins with the SBPs-mediated importation of intact HMOs inside the cytoplasm, then HMOs were assimilated intracellularly by several GHs releasing large quantities of lactic and acetic acid, who play an important role in modulating intestinal physiology and protecting infant gut from pathogen colonization [112-114]. Besides, RNA-seq transcriptomic analysis also revealed that 6'-SL, lacto- $\mathrm{N}$-tetraose, and $\mathrm{LNnT}$ could induce the expression of HMO-utilization genes in the HMO cluster I, whereas 
alternate gene clusters other than HMO cluster I seem to be induced to utilize Fuc during growth in presence of 2'-FL and 3-FL [68]. In brief, all these analyses are crucial for further studies to deepen the understanding of regulatory networks behind $\mathrm{HMO}$ consumption and of how HMO consumption is associated with the gut microbiota establishment in breast-fed infants, underlying the design of novel HMO analogs targeting selected beneficial bifidobacteria $[70,115,116]$.

Apart from promoting the growth of beneficial bacteria, HMO-mediated anti-bacterial effects have been observed in Campylobacter jejuni [117], Escherichia coli pathogenesis $[31,118]$, and Listeria monocytogenes [119-121]. HMOs can also act as antiviral agents to provide protection against a number of viral pathogens, such as norovirus [122, 123], rotavirus [124], and respiratory virus $[125,126]$, through several mechanisms. Besides, despite the limited studies which assess the activity of HMOs against protozoan parasites and fungal species, the findings from these studies demonstrated that HMOs can reduce infection by Entamoeba histolytica [127] and Candida albicans [128]. In conclusion, HMOs have a great influence on infant microbiota, indicating their potential as novel candidates for further developments in food additive to infant formula milk and therapeutics targeting pathogenic infection.

\section{Effects of HMO on infant gut microbiota}

Diverse functions of HMOs have been demonstrated, such as regulating microbiota composition, protecting against pathogen adhesion and infection, and modulating epithelial cell response. In the section below, we will focus on the functions that attribute to HMOs and the mechanism underlying the beneficial effects of HMOs.

\section{Effects of HMO on microbiota composition}

HMOs have an important influence on bacteria colonization in the intestine that is necessary for infant health. In early life, $10^{14}$ bacteria colonized the intestine [129]. The first year of infant life is critical for intestinal microbiome establishment, and infant diet is of importance for gut microbiome development [90]. HMOs are not digested in the top half of the gastrointestinal tract of infants, due to the lack of GHs and intestinal membrane transporters $[130,131]$. As a consequence of high concentration, HMOs can reach both the small and large intestine, where they serve as substrates for resident microbes, affecting the composition and activity of the gastrointestinal microbiota [132] (Fig. 3A). HMOs are specifically known to support the growth of beneficial microorganisms, such as Bifidobacterium [133], which is generally calculating for $50-90 \%$ of the total bacterial population detected in the feces of breastfed infants [134]. Genomic analysis of particular infant-derived Bifidobacterial strains has revealed that aggregation of transporters, $\mathrm{GHs}$, and carbohydrate-binding proteins contributes to the degradation of HMOs [135]. The expression of HMOs-degrading enzymes is mainly limited to $B$. breve, B. bifidum, B. longum, and B. infantis [136, 137]. Besides, Bifidobacteria and Lactobacilli express sialidases and fucosidases to cleave Sia and Fuc, respectively, indicating the coevolution of these species and HMOs [107].

Bifidobacterium also have an impact on other microorganisms composition. Asakuma et al. found that $B$. bifidum can secrete GHs to degrade HMOs extracellularly, and then leave metabolized sugars outside the cells, which are utilized by other bacteria to produce short chain fatty acids (SCFAs) such as butyrate and propionate [138]. Butyric acid and propionic acid are essential for intestinal health given that they can interact with host epithelial cells to stimulate mucin release, increase mucosal blood flow, and regulate immunity [139, 140]. E. hallii, which is a common member of the adult gut microbiota, cannot grow by using Fuc. However, when cocultured with $B$. infantis, it can utilize 1,2-propanediol (1,2-PD), which is produced by $B$. infantis through resolving Fuc, revealing a trophic interaction between $E$. hallii and B. infantis [141].

Apart from the capability of HMOs to modulate the composition of Bifidobacteria in the intestinal tract, they can directly interact with other bacteria and affect the distribution of gut microbes. 2'-FL, 3-FL, 3'-SL, 6'-SL, and lactodifucotetraoseare (LDFT) are metabolized by many Bacteroides [142]. Besides, HMO-derivatives LNB and Lacto- $N$-Triose II can be used by L. casei [143]. In conclusion, though the species of gut microbes except bifidobacteria have low capacity, they still play an important role in intestinal homeostasis of breastfed infants [144].

Additionally, HMOs can pass gut-barrier so that they have an effect outside the intestines [145]. HMOs have been demonstrated to activate $\mathrm{G}$ protein-coupled receptors (GPCRs) which can influence almost every physiological function, such as development, taste, olfaction, regulating heart rate, hormone signaling, and neurotransmission [146] in two ways: one pathway is direct activation by $6^{\prime}-\mathrm{SL}$ and LNT, the second is increased production of kynurenic acid (KYNA) by the microbiota which in turn activates GPR35 [147].

\section{Effects of $\mathrm{HMO}$ on preventing pathogen infection}

Several bacteria, viruses, fungi, and protozoan parasite need to adhere to the glycocalyx (the carbohydrate-rich layer coating epithelial cells) first to invade the host and cause diseases [148], while HMOs can prevent the infection by acting as soluble decoy receptors, which combine 

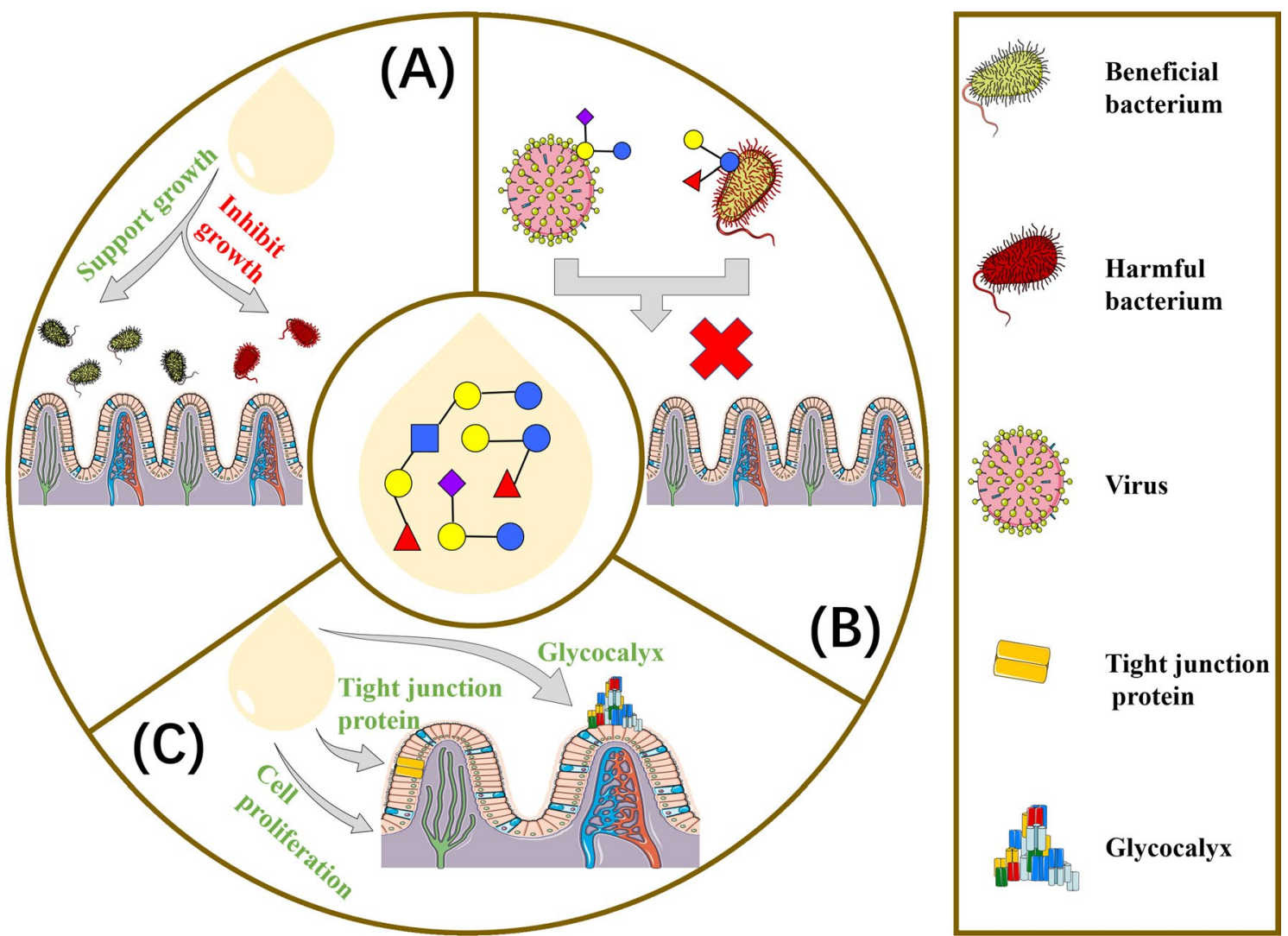

Fig. 3 Schematic summary of main effects of HMOs. A HMOs stimulate growth of beneficial bactria, such as Bififidobacteria, and inhibit growth of harmful bacteria to regulate gut microbiota composition [132]. B HMOs serve as pathogen binding decoy receptors to prevent pathogens from binding to epithelial cell receptors [149]. C HMOs alter glycocalyx [171], influence epithelial cell proliferation [168] and modulate tight junction protein expression [167], thereby reducing permeability of the gut barrier

with pathogens to avoid them from binding to epithelial cell surface receptors, therefore, the pathogens would pass gastrointestinal tract harmlessly [149] (Fig. 3B).

\section{Bacterial infection}

Campylobacter jejuni seems to be one of the most common causes of diarrhea which leads to infants death [150]. 2'-FL acts as a soluble decoy receptor for $C$. jejuni, reducing the colonization of $C$. jejuni by $80 \%$ [117, 151]. Enteropathogenic Escherichia coli (EPEC) can cause serious diarrheal disease leading to high mortality rates in infants. A significant reduction of the pathogenic colonization is observed in cultured epithelial cells by pre-incubating EPEC with mixed HMO components [118]. 2'-FL and LNFP I not only reduce the adhesion of pathogens but also decrease pathogenicity by binding to heat-labile enterotoxin type 1 [31]. It also plays a role in immunity and urinary system. Lately, He et al. found that lipopolysaccharidemediated inflammation was directly inhibited by 2'-FL during the process of enterotoxigenic Escherichia coli
(ETEC) invading T84 and H4 intestinal epithelial cells [152]. Similarly, uropathogenic Escherichia coli (UPEC) would be prevented from attaching to epithelial cell monolayers in the presence of $15 \mathrm{mg} / \mathrm{mL}$ HMOs, which delay the p38 MAPK and p65 NF-kB signaling pathways [153].

Aside from decreasing the adhesion and invasion of pathogens, HMOs can modify the gene expression of epithelial surface and inhibit the growth of pathogens to reduce their infection. After pre-incubating with HMOs, genes of Caco-2Bbe gut cells that mediate the adhesion between intestinal epithelial cells and L. monocytogenes would be downregulated due to the activation of unfolded protein response and eIF2 signaling [119]. Another study revealed that growth and biofilm formation of Group B Streptococci (GBS) can be modulated by HMOs as well. In specific, the concentration of HMOs between 1-2 mg/L delays the growth of GBS up to $96-98 \%$, and LNT and lacto-N-difucohexaose (LNDFH)-I showed the highest capability of inhibition [121]. Besides, the combination of HMOs and 
vancomycin or ciprofloxacin will improve the curative effect of these antibiotics $[120,154]$.

\section{Viral infections}

HMOs can improve infant resistance to two fatal gastrointestinal infections caused by rotavirus and norovirus [124, 155]. Mechanical studies revealed that HMOs provided protection against viral infections by mimicking receptor sites to prevent viruses from entering host cells [156] and stimulate immunity through $\gamma$-interferon and IL-10 expression to decrease virulence [157].

Most recently, $2^{\prime}$-FL, $3^{\prime}$-SL, and $6^{\prime}$-SL were demonstrated to have a notable antiviral activity against G1P[8] and G2P [4] rotavirus. $2^{\prime}$-FL significantly inhibited G1P [8] rotavirus infection, while a conjugate of $3^{\prime}-\mathrm{SL}$ and $6^{\prime}-\mathrm{SL}$ had the strongest ability to inhibit G2P [4] rotavirus infection [124]. However, HMOs cannot inhibit all kinds of rotavirus infections, such as neonatal rotavirus G10P[11], it has a dose-dependent enhancement in infectivity with the increased concentration of LNT and LNnT [155].

HMOs have also been shown to function as antiviral agents to prevent norovirus infection. Histo-blood group antigens (HBGAs), which function as key binding sites for norovirus adhesion, are carbohydrate epitopes not only present in the surface of red blood cells, but also in mucosal epithelium of the gastrointestinal tracts, genitourinary tracts, and the respiratory tubes [28]. They also act as free oligosaccharide fluids in the physiological system $[158,159]$. Norovirus can bind to high-mass HMOs containing abundant $\alpha$-fucose due to the similar structure to HBGAs [122], resulting in the reduced infection of breastfed infants. Similarly, Fuc and Glc were the fermentation products of 2'-FL and 3'-FL, which can connect to GI.1, GII.17, and GII.10 noroviruses by interacting with amino acids expressed in noroviruses to prevent norovirus from binding to HBGAs [123, 160].

In addition to preventing the gut virus, HMOs also can inhibit respiratory virus infections [161]. 2'-FL has been shown to reduce viral load of respiratory syncytial virus [162]. And further research showed that the $2^{\prime}-\mathrm{FL}$ is possible to enhance innate and adaptive immunity in influenza-specific murine model [125].

\section{Protozoan parasite infections}

Beyond acting as an inhibitor of bacterial and viral pathogens, HMOs significantly prevent protozoan parasite infections as well. Entamoeba histolytica is an anaerobic amoebozoan which causes 55,000 deaths worldwide every year [163]. An in vitro study demonstrated that LNT which contains the terminal Gal structure can act as soluble decoy receptors to prevent Entamoeba histolytica from attaching to intestinal epithelial HT-29 cells [127].

\section{Fungal infection}

The impact of intestinal fungus on infant health is especially significant in early gestational age. For example, the invasion rate of systemic candidiasis in infants approximately reaches $10 \%$ and the mortality rate is about $20 \%$ [164]. A recent study showed that HMOs downregulated ALS3 that encoded the C. albicans hyphal-specific adhesion, and nascent hyphae expression, resulting in the reduced adhesion between $C$. albicans and epithelial cells at early infection phase. Additionally, the intestinal epithelial cell binding sites on the surface of $C$. albicans are blocked by HMOs as well [128].

\section{Effects of HMOs on modulating epithelial cell responses}

HMOs not only influence microbes intensely but also have a direct effect on intestinal epithelial cells (Fig. 3C). The intestinal epithelium covering the small intestine and colon is regarded as a paramount part of innate immunity, serving as a physical and speed limit barrier between intestinal cavity and circulatory system [165]. The tight junctions connecting epithelial cells determine the permeability of the epithelium, which is known as permselective barrier. It modulates the process of macromolecules and ions passing the pore and leak ways, avoiding the absorption of harmful microbes and compounds, and regulating the transportation of electrolytes and nutrients [166]. HMOs can modulate the expression of tight junction protein, thereby decrease the permeability and enhance the barrier effect of the epithelium. 2-'FL, 6-'SL, or LNnT can arrest G2/M cell-cycle of HT-29 and Caco-2Bbe, which belongs to small intestinal cell lines, to inhibit the proliferation of HT-29 and Caco-2Bbe in preconfluent phase, leading to the maturation of HT-29 and Caco-2Bbe given that the differentiation and proliferation are inversely proportional in preconfluent cultures; besides, the high concentration of LNnT and $2^{\prime}$-FL can also enhance barrier function and promote digestion [167]. Further study showed that whether HT-29 and Caco-2Bbe were treated with individual or compositional $2^{\prime}$-FL, $3^{\prime}-\mathrm{SL}$ and $6^{\prime}$-SL, the proliferation of them would be reduced and the differentiation would be increased in preconfluent transformation, all of which can promote the maturation of HT-29 and Caco-2Bbe cell lines [168]. Furthermore, HMOs can upregulate the expression of Muc2 which is the predominant form of mucin in the small intestine leading to descended bacterial adhesion and permeability of the intestinal epithelium [169].

The unproper development of glycocalyx on neonatal gut epithelium will disorder the gastrointestinal system [170]. A recent study indicated that $2^{\prime}$-FL and 3 -FL promoted glycocalyx development in a structure-dependent fashion and gut barrier will be enhanced subsequently [171]. Besides, the transformation from sialylation to 
fucosylation benefits the maturation of intestinal epithelium [172], which means HMOs can regulate intestinal epithelial cells through modulation of intestinal glycome [173]. Angeloni et al. discovered that the expression of sialyltransferases ST3Gal1, ST3Gal2, and ST3Gal4 would be decreased in the presence of $3^{\prime}$-FL, leading to the reduction of $\alpha 2-3-$, $\alpha 2-6$-sialylation on Caco-2Bbe surface, which results in the reduced adhesion of $E$. coli by $50 \%$ [174].

HMOs also show indirect effects on epithelium after fermented by $B$. infantis. A study has reported that the conditioned media of $B$. infantis (BCM) enhanced expression of occludin and junctional adhesion molecule in either HT-29 or Caco-2Bbe, which can improve intestinal barrier function [175]. BCM also increased claudin-1 protein expression, by which the gut barrier was strengthened [176]. And the BCM might prevent IL-1b stimulation to protect $\mathrm{Caco}-2 \mathrm{Bbe}$ through NF- $\mathrm{kB}$ pathway as well [177].

\section{Conclusion and future perspectives}

HMOs are complex carbohydrates synthesized in breast gland which are abundant in human milk. Different kinds of HMOs directly or indirectly modulate the infant's physiological systems by regulating microbial composition, preventing pathogens adhesion and invasion, and regulating intestinal epithelial cell response.

Currently, HMOs have been synthesized artificially as additives in infant milk formulations for the infants who cannot be fed with breast milk to support their growth and provide protection against different diseases which have a high morbidity in babys' early years $[171,178]$. Some studies have shown the superior assimilation and toleration of $2^{\prime}$-FL and LNnT by infants $[179,180]$, meanwhile other HMOs still have challenges in expensive synthesis. Given that, the European Union and the United State consider $2^{\prime}$-FL and LNnT are qualified to be used in infant formula [181]. A clinical study showed that formula with 2'-FL can inhibit inflammatory cytokine production and the results of the formula group are similar to the breastfed group [182]. The other study revealed that the formula $2^{\prime}$-FL and LNnT would keep infants healthy whose parents have respiratory tract infections and bronchitis [180]. Recently, it was found that the addition of $2^{\prime}$-FL and LNnT to infant formula would shift the microbiota toward the microbiota of breastfed babies, which would increase the quantity of Bifidobacteria and decrease the number of Clostridium difficile [183].

The application of HMOs in therapeutic area has been reported in recent years. For instance, HMOs have therapeutic potential in food allergies. HMO supplementation study was conducted in an ovalbumin sensitized mouse model consuming 2'-FL and $6^{\prime}$-FL. As a consequence,
$2^{\prime}$-FL and $6^{\prime}$-FL would indirectly stabilize mast cells by inducing expression of $\mathrm{T}$ regulatory cells, and activate the IL-10(+) regulatory cells to reduce the symptoms of food allergy [184]. Especially, 6'-FL can suppress the immune system greatly by decreasing inflammatory factors and chemokines, which inhibit inflammatory cells from flocking in the intestine [184]. Analogously, FUT2-dependent breast milk oligosaccharides reduced the occurrence of IgE-associated disease and IgE-associated eczema in cesarean section born infants [185]. In contrast to these findings, pro-inflammatory effect of 3'-SL was reported in a mesenteric lymph node $\mathrm{CD} 11(+)$ dendritic cells exposed to $3^{\prime}-\mathrm{SL}$, which can generate cytokines that increase the quantity of Th1 and Th17 immune cell [186]. Besides, clinical studies have confirmed that HMOs contribute to the positive effects of human milk against necrotizing enterocolitis (NEC) which is a fatal gastrointestinal disease in very low birth weight (VLBW) infants [187]. DSLNT in breast milk could be used to prevent NEC in formula-fed infants, and its concentration in the mother's milk could act as a potential non-invasive marker to identify whether infants are at risk of NEC [187], while another study including 96 mothers and 106 VLBW infants demonstrated a contradictory result that DSLNT was not significantly associated with NEC [178]. $2^{\prime}$-FL, 3'-SL, 6'-SL, and LNnT also have a protective effect on the development of autoimmune diseases such as type-1 diabetes (T1D) which is caused by autoimmune destruction of insulin-producing $\beta$ cells of the pancreas. Animal research revealed that HMOs were prone to balance Th1/Th17 immune responses of non-obese diabetic (NOD)-mice, which would reduce T1D occurrence rate and inhibit pancreatic insulitis progress [125]. Metabolic products of HMOs have been demonstrated in field of cognition development [67]. An animal study showed the dietary 2 '-FL improved cognitive abilities, learning and memory in rodents [188]. Furthermore, 3'-SL and 6'-SL were able to supported normal microbial communities and behavioral responses in stressor-exposed mice to prevent stressor-induced effect, and the result revealed the evidence of gut microbiota-brain axis [189].

HMOs not merely affect infants, but also have an influence on adults. $2^{\prime}$-FL and LNnT can change the microorganisms composition of adults, which increasing the amount of Bifidobacterium and Actinobacteria, and decreasing Proteobacteria and Firmicute [190]. Another study revealed that Caco-2Bbe treated with 2 '-FL for 3 weeks showed reduced permeability of monolayers, and tight junction proteins, such as claudin-5 and claudin- 8 were upregulated, which strengthen the gut barrier in adults [191].

In conclusion, HMO plays a special role in the prevention and treatment of diseases, thereby maintaining the 
health of infants and adults. Therefore, the prospect of HMO will be exciting, both for the prevention of single disease and multiple combined diseases.

\begin{abstract}
Abbreviations
WHO: World Health Organization; HMOs: Human milk oligosaccharides; OS: Oligosaccharides; GlcNAc: N-acetylglucosamine; Sia: Sialic acid; Fuc: L-fucose; Gal: D-galactose; Glc: D-glucose; LNB: Lacto-N-biose; FucOS: Fucosylated OS; SiaOS: Sialylated OS; Se: Secretor; Le: Lewis; FUT2: a1-2-Fucosyltransferase enzyme; FUT3: a1-3/4-Fucosyltransferase; LNFP: Lacto-N-fucopentaose; FL: Fucosyllactose; DSLNT: Disialyllacto-N-tetraose; LSTa: LS-tetrasaccharide; SL: Sialyllactose; iGnT: $\beta 1,3-N$-acetylglucosaminyltransferase; IGnT: $\beta 1,6-N$ acetylglucosaminyltransferase; LNT: Lacto-N-tetraose; ABC: Adenosine triphosphate binding cassette; GHs: Glycosyl hydrolases; LnbX: Lactam-N-biogenase; LSTb: Sialyllacto-N-tetraose b; MFLNH: Monofucosyllacto-N-hexaose; LNH: Acto-N-hexaose; LNnT: Lacto-N-neotetraose; SBPs: Family 1 solute binding proteins; SCFAs: Short chain fatty acids; 1,2-PD: 1,2-Propanediol; LDFT: Lactodifucotetraoseare; GPCRs: G protein-coupled receptors; KYNA: Kynurenic acid; EPEC: Enteropathogenic Escherichia coli; ETEC: Enterotoxigenic Escherichia coli; UPEC: Uropathogenic Escherichia coli; GBS: Group B Streptococci; LNDFH: Lacto-N-difucohexaose; HBGAs: Histo-blood group antigens; BCM: Conditioned media of B infantis: NEC: Necrotizing enterocolitis:VLBW:Very low birth weight; LNDH I: Lacto-N-difucohexaose; T1D: Type-1 diabetes; NOD: Non-obese diabetic
\end{abstract}

\section{Acknowledgements}

Not applicable.

\section{Authors' contributions}

SHZ, TLL, LYZ, and WBY contributed to conception and design. SHZ, TLL contributed to manuscript writing and figures making. JX, DMZ, CXP, LYZ, and WBY critically viewed, edited and approved the manuscript. All authors read and approved the final manuscript. SHZ and TLL contributed equally to this work.

\section{Funding}

This work was supported by grants from The Research and Development Foundation of West China Hospital of Stomatology, Sichuan University (RD02-201907) to Dr. Wenbin Yang. This work was also funded by Natural Science Foundation of China 81802468, Sichuan Science and Technology Program 2019 YFS0207 and China Postdoctoral Science Foundation 2020M670062ZX to Dr. Lingyun Zhou.

\section{Availability of data and materials}

Not applicable.

\section{Declarations}

Ethics approval and consent to participate

Not applicable.

\section{Consent for publication}

Not applicable.

\section{Competing interests}

The authors declare that they have no competing interests.

\section{Author details}

${ }^{1}$ State Key Laboratory of Oral Disease, National Clinical Research Center for Oral Disease, West China Hospital of Stomatology, Sichuan University, Chengdu 610041, Sichuan, China. ${ }^{2}$ Center of Infectious Diseases, West China Hospital of Sichuan University, No. 37 Guoxue Alley, Wuhou District, Chengdu 610041, China. ${ }^{3}$ State Key Laboratory of Oral Diseases, National Clinical Research Center for Oral Diseases, Department of Oral and Maxillofacial Surgery, Department of Medical Affairs, West China Hospital of Stomatology, Sichuan University, No. 14, Section 3, South Renmin Road, Chengdu 610041, Sichuan, China.
Received: 1 December 2020 Accepted: 21 May 2021

Published online: 28 May 2021

\section{References}

1. Gallie S, Vocking K, Post JA, Van De Heijning B, Acton D, Van Der Beek EM, Van Baalen T. A novel infant milk formula concept: Mimicking the human milk fat globule structure. Coll Surf B Biointerfaces. 2015;136:329-39. https://doi.org/10.1016/j.colsurfb.2015.09.024.

2. Walker A. Breast milk as the gold standard for protective nutrients. J Pediatr. 2010;156(2 Suppl):S3-7. https://doi.org/10.1016/j.jpeds.2009.11. 021.

3. Oftedal OT. The evolution of milk secretion and its ancient origins. Animal. 2012;6(3):355-68. https://doi.org/10.1017/S1751731111001935.

4. Donovan SM. Summary on clinical aspects of human milk on infant health outcomes. Nestle Nutr Inst Workshop Ser. 2019;90:175-8. https:// doi.org/10.1159/000490485.

5. Dieterich CM, Felice JP, O'Sullivan E, Rasmussen KM. Breastfeeding and health outcomes for the mother-infant dyad. Pediatr Clin North Am. 2013;60(1):31-48. https://doi.org/10.1016/j.pcl.2012.09.010.

6. Section on, B. Breastfeeding and the use of human milk. Pediatrics, 2012, 129(3): e827-41. https://doi.org/10.1542/peds.2011-3552.

7. Klopp A, Vehling L, Becker AB, Subbarao P, Mandhane PJ, Turvey SE, Lefebvre DL, Sears MR, Investigators CS, Azad MB. Modes of infant feeding and the risk of childhood asthma: a prospective birth cohort study. J Pediatr. 2017;190:192-9. https://doi.org/10.1016/j.jpeds.2017.07.012.

8. Dogaru CM, Nyffenegger D, Pescatore AM, Spycher BD, Kuehni CE. Breastfeeding and childhood asthma: systematic review and metaanalysis. Am J Epidemiol. 2014;179(10):1153-67. https://doi.org/10. 1093/aje/kwu072

9. den Dekker HT, Sonnenschein-van der Voort AM, Jaddoe VW, Reiss IK, de Jongste JC, Duijts L. Breastfeeding and asthma outcomes at the age of 6 years: The Generation R Study. Pediatr Allergy Immunol. 2016:27(5):486-92. https://doi.org/10.1111/pai.12576.

10. Azad MB, Vehling L, Lu Z, Dai D, Subbarao P, Becker AB, Mandhane PJ, Turvey SE, Lefebvre DL, Sears MR, CS Investigators. Breastfeeding, maternal asthma and wheezing in the first year of life: a longitudinal birth cohort study. Eur Respir J. 2017. https://doi.org/10.1183/13993 003.02019-2016.

11. Horta BL, Loret C, de Mola CG, Victora. . Long-term consequences of breastfeeding on cholesterol, obesity, systolic blood pressure and type 2 diabetes: a systematic review and meta-analysis. Acta Paediatr. 2015:104(467):30-7. https://doi.org/10.1111/apa.13133.

12. Xu L, Lochhead P, Ko Y, Claggett B, Leong RW, Ananthakrishnan AN. Systematic review with meta-analysis: breastfeeding and the risk of Crohn's disease and ulcerative colitis. Aliment Pharmacol Ther. 2017;46(9):7809. https://doi.org/10.1111/apt.14291.

13. Del Ciampo LA, Del Ciampo IRL. Breastfeeding and the Benefits of Lactation for Women's Health. Rev Bras Ginecol Obstet. 2018:40(6):354-9. https://doi.org/10.1055/s-0038-1657766.

14. O'Sullivan A, Salcedo J, Rubert J. Advanced analytical strategies for measuring free bioactive milk sugars: from composition and concentrations to human metabolic response. Anal Bioanal Chem. 2018:410(15):3445-62. https://doi.org/10.1007/s00216-018-0913-1.

15. Chouraqui JP. Does the contribution of human milk oligosaccharides to the beneficial effects of breast milk allow us to hope for an improvement in infant formulas?. Crit Rev Food Sci Nutr. 2020. https://doi.org/ 10.1080/10408398.2020.1761772.

16. Gauhe A, Gyorgy P, Hoover JR, Kuhn R, Rose CS, Ruelius HW, Zilliken F. Bifidus factor. IV. Preparations obtained from human milk. Arch Biochem Biophys. 1954;48(1):214-24. https://doi.org/10.1016/00039861(54)90326-4.

17. Gyorgy P, Kuhn R, Rose CS, Zilliken F. Bifidus factor. II. Its occurrence in milk from different species and in other natural products. Arch Biochem Biophys. 1954;48(1):202-8. https://doi.org/10.1016/0003-9861(54) 90324-0.

18. Gyorgy P, Norris RF, Rose CS. Bifidus factor. I. A variant of Lactobacillus bifidus requiring a special growth factor. Arch Biochem Biophys. 1954:48(1):193-201. https://doi.org/10.1016/0003-9861(54)90323-9. 
19. Austin SC, De Castro A, Sprenger N, Binia A, Affolter M, Garcia-Rodenas $\mathrm{CL}$, Beauport L, Tolsa JF, Fischer Fumeaux CJ. Human milk oligosaccharides in the milk of mothers delivering term versus preterm infants. Nutrients. 2019. https://doi.org/10.3390/nu11061282.

20. Andreas NJ, Kampmann B, Mehring Le-Doare K. Human breast milk: a review on its composition and bioactivity. Early Hum Dev. 2015;91(11):629-35. https://doi.org/10.1016/j.earlhumdev.2015.08.013.

21. Ballard O, Morrow AL. Human milk composition: nutrients and bioactive factors. Pediatr Clin North Am. 2013;60(1):49-74. https://doi.org/10. 1016/j.pcl.2012.10.002.

22. Urashima T, Taufik E, Fukuda K, Asakuma S. Recent advances in studies on milk oligosaccharides of cows and other domestic farm animals. Biosci Biotechnol Biochem. 2013;77(3):455-66. https://doi.org/10.1271/ bbb.120810.

23. Kunz C, Rudloff S, Baier W, Klein N, Strobel S. Oligosaccharides in human milk: structural, functional, and metabolic aspects. Annu Rev Nutr. 2000;20:699-722. https://doi.org/10.1146/annurev.nutr.20.1.699.

24. Smilowitz JT, Lebrilla CB, Mills DA, German JB, Freeman SL. Breast milk oligosaccharides: structure-function relationships in the neonate. Annu Rev Nutr. 2014;34:143-69. https://doi.org/10.1146/annur ev-nutr-071813-105721.

25. Rautava S, Luoto R, Salminen S, Isolauri E. Microbial contact during pregnancy, intestinal colonization and human disease. Nat Rev Gastroenterol Hepatol. 2012;9(10):565-76. https://doi.org/10.1038/nrgastro. 2012.144.

26. Scholtens PA, Oozeer R, Martin R, Amor KB, Knol J. The early settlers: intestinal microbiology in early life. Annu Rev Food Sci Technol. 2012;3:425-47. https://doi.org/10.1146/annurev-food-022811-101120.

27. Ruiz L, Delgado S, Ruas-Madiedo P, Margolles A, Sanchez B. Proteinaceous molecules mediating bifidobacterium-host interactions. Front Microbiol. 2016;7:1193. https://doi.org/10.3389/fmicb.2016.01193.

28. Morozov V, Hansman G, Hanisch FG, Schroten H, Kunz C. Human milk oligosaccharides as promising antivirals. Mol Nutr Food Res. 2018;62(6):e1700679. https://doi.org/10.1002/mnfr.201700679.

29. Bode L, Jantscher-Krenn E. Structure-function relationships of human milk oligosaccharides. Adv Nutr. 2012;3(3):3835-91S. https://doi.org/10. 3945/an.111.001404.

30. Bode L. The functional biology of human milk oligosaccharides. Early Hum Dev. 2015;91(11):619-22. https://doi.org/10.1016/j.earlhumdev. 2015.09.001.

31. El-Hawiet A, Kitova EN, Klassen JS. Recognition of human milk oligosaccharides by bacterial exotoxins. Glycobiology. 2015;25(8):845-54. https://doi.org/10.1093/glycob/cwv025.

32. He Y, Lawlor NT, Newburg DS. Human milk components modulate toll-like receptor-mediated inflammation. Adv Nutr. 2016;7(1):102-11. https://doi.org/10.3945/an.115.010090.

33. McGuire MK, McGuire MA. Human milk: mother nature's prototypical probiotic food?. Adv Nutr. 2015;6(1):112-23. https://doi.org/10.3945/an. 114.007435 .

34. Thurl S, Munzert M, Boehm G, Matthews C, Stahl B. Systematic review of the concentrations of oligosaccharides in human milk. Nutr Rev. 2017;75(11):920-33. https://doi.org/10.1093/nutrit/nux044.

35. Xu G, Davis JC, Goonatilleke E, Smilowitz JT, German JB, Lebrilla CB. Absolute Quantitation of Human Milk Oligosaccharides Reveals Phenotypic Variations during Lactation. J Nutr. 2017;147(1):117-24. https://doi. org/10.3945/jn.116.238279.

36. Chen X. Human milk oligosaccharides (HMOS): structure, function, and enzyme-catalyzed synthesis. Adv Carbohydr Chem Biochem. 2015;72:113-90. https://doi.org/10.1016/bs.accb.2015.08.002.

37. Liu Z, Auldist M, Wright M, Cocks B, Rochfort S. Bovine milk oligosaccharide contents show remarkable seasonal variation and intercow variation. J Agric Food Chem. 2017;65(7):1307-13. https://doi.org/10. 1021/acs.jafc.6b04098.

38. Robinson RC. Structures and metabolic properties of bovine milk oligosaccharides and their potential in the development of novel therapeutics. Front Nutr. 2019;6:50. https://doi.org/10.3389/fnut.2019.00050.

39. Kuntz S, Rudloff S, Kunz C. Milk oligosaccharides from different cattle breeds influence growth-related characteristics of intestinal cells. Front Nutr. 2019;6:31. https://doi.org/10.3389/fnut.2019.00031.
40. Kumazaki T, Yoshida A. Biochemical evidence that secretor gene, Se, is a structural gene encoding a specific fucosyltransferase. Proc Natl Acad Sci U S A. 1984;81(13):4193-7. https://doi.org/10.1073/pnas.81.13.4193.

41. Kunz C, Meyer C, Collado MC, Geiger L, Garcia-Mantrana I, Bertua-Rios B, Martinez-Costa C, Borsch C, Rudloff S. Influence of gestational age, decretor, and Lewis blood group status on the oligosaccharide content of human milk. J Pediatr Gastroenterol Nutr. 2017;64(5):789-98. https:// doi.org/10.1097/MPG.0000000000001402.

42. Johnson PH, Watkins WM. Purification of the Lewis blood-group gene associated alpha-3/4-fucosyltransferase from human milk: an enzyme transferring fucose primarily to type 1 and lactose-based oligosaccharide chains. Glycoconj J. 1992;9(5):241-9. https://doi.org/10.1007/BF007 31136.

43. Donovan SM, Comstock SS. Human milk oligosaccharides influence neonatal mucosal and systemic immunity. Ann Nutr Metab. 2016;69(Suppl 2):42-51. https://doi.org/10.1159/000452818.

44. Ayechu-Muruzabal V, van Stigt AH, Mank M, Willemsen LEM, Stahl B, Garssen J, Van't Land B. Diversity of human milk oligosaccharides and effects on early life immune development. Front Pediatr. 2018;6:239. https://doi.org/10.3389/fped.2018.00239.

45. Azad MB, Robertson B, Atakora F, Becker AB, Subbarao P, Moraes TJ, Mandhane PJ, Turvey SE, Lefebvre DL, Sears MR, Bode L. Human milk oligosaccharide concentrations are associated with multiple fixed and modifiable maternal characteristics, environmental factors, and feeding practices. J Nutr. 2018;148(11):1733-42. https://doi.org/10.1093/jn/ nxy 175.

46. Bai Y, Tao J, Zhou J, Fan Q, Liu M, Hu Y, Xu Y, Zhang L, Yuan J, Li W, Ze X, Malard P, Guo Z, Yan J, Li M. Fucosylated human milk oligosaccharides and $\mathrm{N}$-glycans in the milk of Chinese mothers regulate the gut microbiome of their breast-fed infants during different lactation stages. mSystems. 2018. https://doi.org/10.1128/mSystems.00206-18.

47. McGuire MK, Meehan CL, McGuire MA, Williams JE, Foster J, Sellen DW, Kamau-Mbuthia EW, Kamundia EW, Mbugua S, Moore SE, Prentice AM, Kvist LJ, Otoo GE, Brooker SL, Price WJ, Shafii B, Placek C, Lackey KA, Robertson B, Manzano S, Ruiz L, Rodriguez JM, Pareja RG, Bode L. What's normal? Oligosaccharide concentrations and profiles in milk produced by healthy women vary geographically. Am J Clin Nutr. 2017;105(5):1086-100. https://doi.org/10.3945/ajcn.116.139980.

48. Elwakiel M, Hageman JA, Wang W, Szeto IM, van Goudoever JB, Hettinga KA, Schols HA. Human milk oligosaccharides in colostrum and mature milk of Chinese mothers: Lewis positive secretor subgroups. J Agric Food Chem. 2018;66(27):7036-43. https://doi.org/10.1021/acs. jafc.8b02021.

49. Tonon MK, de Morais BM, Abrão AC, Miranda A, Morais BT. Maternal and infant factors associated with human milk oligosaccharides concentrations according to secretor and Lewis phenotypes. Nutrients. 2019. https://doi.org/10.3390/nu11061358.

50. van Leeuwen SS, Stoutjesdijk E, Ten Kate GA, Schaafsma A, DijckBrouwer J, Muskiet FAJ, Dijkhuizen L. Regional variations in human milk oligosaccharides in Vietnam suggest FucTx activity besides FucT2 and FucT3. Sci Rep. 2018;8(1):16790. https://doi.org/10.1038/ s41598-018-34882-x.

51. Yan J, Ding J, Jin G, Duan Z, Yang F, Li D, Zhou H, Li M, Guo Z, Chai W, Liang X. Profiling of Human Milk Oligosaccharides for Lewis Epitopes and Secretor Status by Electrostatic Repulsion Hydrophilic Interaction Chromatography Coupled with Negative-lon Electrospray Tandem Mass Spectrometry. Anal Chem. 2019;91(13):8199-206. https://doi.org/ 10.1021/acs.analchem.9b00687.

52. ten Bruggencate $\mathrm{SJ}$, Bovee-Oudenhoven IM, Feitsma AL, van Hoffen $\mathrm{E}$, Schoterman MH. Functional role and mechanisms of sialyllactose and other sialylated milk oligosaccharides. Nutr Rev. 2014;72(6):377-89. https://doi.org/10.1111/nure.12106.

53. Bode L. Human milk oligosaccharides at the interface of maternalinfant health. Breastfeed Med. 2018;13(S1):S7-8. https://doi.org/10. 1089/bfm.2018.29073.ljb.

54. Goehring KC, Kennedy AD, Prieto PA, Buck RH. Direct evidence for the presence of human milk oligosaccharides in the circulation of breastfed infants. PLoS ONE. 2014;9(7):e101692. https://doi.org/10.1371/journal. pone.0101692. 
55. Bode L. Human milk oligosaccharides: every baby needs a sugar mama. Glycobiology. 2012;22(9):1147-62. https://doi.org/10.1093/glycob/ cWs074.

56. Kobata A. Structures and application of oligosaccharides in human milk. Proc Jpn Acad Ser B Phys Biol Sci. 2010;86(7):731-47. https://doi. org/10.2183/pjab.86.731.

57. Davis JC, Lewis ZT, Krishnan S, Bernstein RM, Moore SE, Prentice AM, Mills DA, Lebrilla CB, Zivkovic AM. Growth and morbidity of Gambian infants are influenced by maternal milk oligosaccharides and infant gut microbiota. Sci Rep. 2017;7:40466. https://doi.org/10.1038/srep40466.

58. Seppo AE, Kukkonen AK, Kuitunen M, Savilahti E, Yonemitsu C, Bode $\mathrm{L}$, Jarvinen KM. Association of Maternal Probiotic Supplementation With Human Milk Oligosaccharide Composition. JAMA Pediatr. 2019;173(3):286-8. https://doi.org/10.1001/jamapediatrics.2018.4835.

59. Qiao Y, Feng J, Yang J, Gu G. The relationship between dietary vitamin A intake and the levels of sialic acid in the breast milk of lactating women. J Nutr Sci Vitaminol. 2013;59(4):347-51. https://doi.org/10.3177/jnsv.59. 347.

60. Jorgensen JM, Arnold C, Ashorn P, Ashorn U, Chaima D, Cheung YB, Davis JC, Fan YM, Goonatilleke E, Kortekangas E, Kumwenda C, Lebrilla CB, Maleta K, Totten SM, Wu LD, Dewey KG. Lipid-based nutrient supplements during pregnancy and lactation did not affect human milk oligosaccharides and bioactive proteins in a randomized trial. J Nutr. 2017;147(10):1867-74. https://doi.org/10.3945/jn.117.252981.

61. Tonon KM, Miranda A, Abrao A, de Morais MB, Morais TB. Validation and application of a method for the simultaneous absolute quantification of 16 neutral and acidic human milk oligosaccharides by graphitized carbon liquid chromatography - electrospray ionization - mass spectrometry. Food Chem. 2019;274:691-7. https://doi.org/10.1016/j.foodc hem.2018.09.036.

62. Dotz V, Rudloff S, Meyer C, Lochnit G, Kunz C. Metabolic fate of neutral human milk oligosaccharides in exclusively breast-fed infants. Mol Nutr Food Res. 2015;59(2):355-64. https://doi.org/10.1002/mnfr.201400160.

63. Underwood MA, Gaerlan S, De Leoz ML, Dimapasoc L, Kalanetra KM, Lemay DG, German JB, Mills DA, Lebrilla CB. Human milk oligosaccharides in premature infants: absorption, excretion, and influence on the intestinal microbiota. Pediatr Res. 2015;78(6):670-7. https://doi.org/10. 1038/pr.2015.162.

64. Gnoth MJ, Kunz C, Kinne-Saffran E, Rudloff S. Human milk oligosaccharides are minimally digested in vitro. J Nutr. 2000;130(12):3014-20. https://doi.org/10.1093/jn/130.12.3014.

65. Liu Z, Subbaraj A, Fraser K, Jia H, Chen W, Day L, Roy NC, Young W. Human milk and infant formula differentially alters the microbiota composition and functional gene relative abundance in the small and large intestines in weanling rats. Eur J Nutr. 2020;59(5):2131-43. https:// doi.org/10.1007/s00394-019-02062-w.

66. Wang M, Li M, Wu S, Lebrilla CB, Chapkin RS, Ivanov I, Donovan SM. Fecal microbiota composition of breast-fed infants is correlated with human milk oligosaccharides consumed. J Pediatr Gastroenterol Nutr. 2015;60(6):825-33. https://doi.org/10.1097/MPG.0000000000000752.

67. Jacobi SK, Yatsunenko T, Li D, Dasgupta S, Yu RK, Berg BM, Chichlowski $\mathrm{M}$, Odle J. Dietary isomers of sialyllactose increase ganglioside sialic acid concentrations in the Corpus Callosum and Cerebellum and Modulate the colonic microbiota of formula-fed piglets. J Nutr. 2016;146(2):200-8. https://doi.org/10.3945/jn.115.220152.

68. Garrido D, Ruiz-Moyano S, Lemay DG, Sela DA, German JB, Mills DA. Comparative transcriptomics reveals key differences in the response to milk oligosaccharides of infant gut-associated bifidobacteria. Sci Rep. 2015;5:13517. https://doi.org/10.1038/srep13517.

69. Kitaoka M. Bifidobacterial enzymes involved in the metabolism of human milk oligosaccharides. Adv Nutr. 2012;3(3):422S-S429. https:// doi.org/10.3945/an.111.001420.

70. Thomson P, Medina DA, Garrido D. Human milk oligosaccharides and infant gut bifidobacteria:m strategies for their utilization. Food Microbiol. 2018;75:37-46. https://doi.org/10.1016/j.fm.2017.09.001.

71. Yamada C, Gotoh A, Sakanaka M, Hattie M, Stubbs KA, Katayama-lkegami A, Hirose J, Kurihara S, Arakawa T, Kitaoka M, Okuda S, Katayama T, Fushinobu S. Molecular insight into evolution of symbiosis between breast-fed infants and a member of the human gut microbiome bifidobacterium longum. Cell Chem Biol. 2017;24(4):515-24. https://doi.org/ 10.1016/j.chembiol.2017.03.012.
72. Lawson MAE, Neill IJ, Kujawska M, GowrinadhJavvadi S, Wijeyesekera A, Flegg Z, Chalklen L, Hall LJ. Breast milk-derived human milk oligosaccharides promote Bifidobacterium interactions within a single ecosystem. ISME J. 2020;14(2):635-48. https://doi.org/10.1038/ s41396-019-0553-2.

73. Zabel B, Yde CC, Roos P, Marcussen J, Jensen HM, Salli K, Hirvonen J, Ouwehand AC, Morovic W. Novel genes and metabolite trends in Bifidobacterium longum subsp. infantis Bi-26 metabolism of human milk oligosaccharide 2'-fucosyllactose. Sci Rep. 2019;9(1):7983. https://doi. org/10.1038/s41598-019-43780-9.

74. Marcobal A, Barboza M, Froehlich JW, Block DE, German JB, Lebrilla CB, Mills DA. Consumption of human milk oligosaccharides by gut-related microbes. J Agric Food Chem. 2010;58(9):5334-40. https://doi.org/10. $1021 / j f 9044205$.

75. Boehm G, Jelinek J, Knol J, M'Rabet L, Stahl B, Vos P, Garssen J. Prebiotics and immune responses. J Pediatr Gastroenterol Nutr. 2004;39(Suppl 3):S772-3. https://doi.org/10.1097/00005176-200406003-00027.

76. De Leoz ML, Kalanetra KM, Bokulich NA, Strum JS, Underwood MA, German JB, Mills DA, Lebrilla CB. Human milk glycomics and gut microbial genomics in infant feces show a correlation between human milk oligosaccharides and gut microbiota: a proof-of-concept study. J Proteome Res. 2015;14(1):491-502. https://doi.org/10.1021/pr500759e.

77. Kulinich A, Liu L. Human milk oligosaccharides: The role in the finetuning of innate immune responses. Carbohydr Res. 2016;432:62-70. https://doi.org/10.1016/j.carres.2016.07.009.

78. Vazquez E, Santos-Fandila A, Buck R, Rueda R, Ramirez M. Major human milk oligosaccharides are absorbed into the systemic circulation after oral administration in rats. Br J Nutr. 2017;117(2):237-47. https://doi.org/ 10.1017/S0007114516004554.

79. Jantscher-Krenn E, Aigner J, Reiter B, Kofeler H, Csapo B, Desoye G, Bode $L$, van Poppel MNM. Evidence of human milk oligosaccharides in maternal circulation already during pregnancy: a pilot study. Am J Physiol Endocrinol Metab. 2019;316(3):E347-57. https://doi.org/10.1152/ajpen do.00320.2018

80. Wise A, Robertson B, Choudhury B, Rautava S, Isolauri E, Salminen S, Bode L. Infants are exposed to human milk oligosaccharides already in utero. Front Pediatr. 2018;6:270. https://doi.org/10.3389/fped.2018. 00270.

81. Underwood MA, German JB, Lebrilla CB, Mills DA. Bifidobacterium longum subspecies infantis: champion colonizer of the infant gut. Pediatr Res. 2015;77(1-2):229-35. https://doi.org/10.1038/pr.2014.156.

82. Backhed F, Roswall J, Peng Y, Feng Q, Jia H, Kovatcheva-Datchary P, Li Y, Xia Y, Xie H, Zhong H, Khan MT, Zhang J, Li J, Xiao L, Al-Aama J, Zhang D, Lee YS, Kotowska D, Colding C, Tremaroli V, Yin Y, Bergman S, Xu X, Madsen L, Kristiansen K, Dahlgren J, Wang J. Dynamics and Stabilization of the Human Gut Microbiome during the First Year of Life. Cell Host Microbe. 2015;17(5):690-703. https://doi.org/10.1016/j.chom.2015.04. 004.

83. Ray K. Gut microbiota: First steps in the infant gut microbiota. Nat Rev Gastroenterol Hepatol. 2016;13(8):437. https://doi.org/10.1038/nrgastro. 2016.108.

84. Morrison DJ, Preston T. Formation of short chain fatty acids by the gut microbiota and their impact on human metabolism. Gut Microbes. 2016;7(3):189-200. https://doi.org/10.1080/19490976.2015.1134082.

85. Fukuda S, Toh H, Hase K, Oshima K, Nakanishi Y, Yoshimura K, Tobe T, Clarke JM, Topping DL, Suzuki T, Taylor TD, Itoh K, Kikuchi J, Morita H, Hattori M, Ohno H. Bifidobacteria can protect from enteropathogenic infection through production of acetate. Nature. 2011;469(7331):543-7. https://doi.org/10.1038/nature09646.

86. Roberfroid, M, G R Gibson, L Hoyles, A L McCartney, R Rastall, I Rowland, D Wolvers, B Watzl, H Szajewska, B Stahl, F Guarner, F Respondek, K Whelan, V Coxam, M J Davicco, L Leotoing, Y Wittrant, N M Delzenne, P D Cani, A M Neyrinck, A Meheust. Prebiotic effects: metabolic and health benefits. Br J Nutr, 2010. https://doi.org/10.1017/S000711451 0003363.

87. H Sugahara, T Odamaki, N Hashikura, F Abe, JZ Xiao. Differences in folate production by bifidobacteria of different origins. Biosci Microbiota Food Health, 2015, 34(4): 87-93. https://doi.org/10.12938/bmfh. 2015-003.

88. Huda MN, Lewis Z, Kalanetra KM, Rashid M, Ahmad SM, Raqib R, Qadri F, Underwood MA, Mills DA, Stephensen CB. Stool microbiota and vaccine 
responses of infants. Pediatrics. 2014;134(2):e362-72. https://doi.org/10. 1542/peds.2013-3937.

89. Kalliomaki M, Kirjavainen P, Eerola E, Kero P, Salminen S, Isolauri E. Distinct patterns of neonatal gut microflora in infants in whom atopy was and was not developing. J Allergy Clin Immunol. 2001;107(1):129-34. https://doi.org/10.1067/mai.2001.111237.

90. Tamburini S, Shen N, Wu HC, Clemente JC. The microbiome in early life: implications for health outcomes. Nat Med. 2016;22(7):713-22. https:// doi.org/10.1038/nm.4142.

91. Yatsunenko T, Rey FE, Manary MJ, Trehan I, Dominguez-Bello MG, Contreras M, Magris M, Hidalgo G, Baldassano RN, Anokhin AP, Heath AC, Warner B, Reeder J, Kuczynski J, Caporaso JG, Lozupone CA, Lauber C, Clemente JC, Knights D, Knight R, Gordon J. Human gut microbiome viewed across age and geography. Nature. 2012;486(7402):222-7. https://doi.org/10.1038/nature11053.

92. Bertelsen RJ, Jensen ET, Ringel-Kulka T. Use of probiotics and prebiotics in infant feeding. Best Pract Res Clin Gastroenterol. 2016;30(1):39-48. https://doi.org/10.1016/j.bpg.2016.01.001.

93. Modesto M, Watanabe K, Arita M, Satti M, Oki K, Sciavilla P, Patavino C, Camma C, Michelini S, Sgorbati B, Mattarelli P. Bifidobacterium jacchi sp. nov., isolated from the faeces of a baby common marmoset (Callithrix jacchus). Int J Syst Evol Microbiol. 2019;69(8):2477-85. https://doi.org/ 10.1099/ijsem.0.003518.

94. Modesto M, Satti M, Watanabe K, Puglisi E, Morelli L, Huang CH, Liou JS, Miyashita M, Tamura T, Saito S, Mori K, Huang L, Sciavilla P, Sandri C, Spiezio C, Vitali F, Cavalieri D, Perpetuini G, Tofalo R, Bonetti A, Arita M, Mattarelli P. Characterization of Bifidobacterium species in feaces of the Egyptian fruit bat: Description of $B$. vespertilionis sp. nov. and B. rousetti sp. nov.. Syst Appl Microbiol. 2019;42(6):126017. https://doi.org/10. 1016/j.syapm.2019.126017.

95. Duranti S, Lugli GA, Napoli S, Anzalone R, Milani C, Mancabelli L, Alessandri G, Turroni F, Ossiprandi MC, van Sinderen D, Ventura M. Characterization of the phylogenetic diversity of five novel species belonging to the genus Bifidobacterium: Bifidobacterium castoris sp nov., Bifidobacterium callimiconis sp. nov., Bifidobacterium goeldii sp. nov., Bifidobacterium samirii sp. nov. and Bifidobacterium dolichotidis sp. nov. Int J Syst Evol Microbiol. 2019;69(5):1288-98. https://doi.org/10. 1099/ijsem.0.003306.

96. Alberoni D, Gaggia F, Baffoni L, Modesto MM, Biavati B, Di Gioia D. Bifdobacterium xylocopae sp. nov. and Bifidobacterium aemilianum sp. nov. from the carpenter bee (Xylocopa violacea) digestive tract. Syst Appl Microbiol. 2019:42(2):205-16. https://doi.org/10.1016/.syapm.2018.11. 005.

97. Lewis ZT, Totten SM, Smilowitz JT, Popovic M, Parker E, Lemay DG, Van Tassell ML, Miller MJ, Jin YS, German JB, Lebrilla CB, Mills DA. Maternal fucosyltransferase 2 status affects the gut bifidobacterial communities of breastfed infants. Microbiome. 2015;3:13. https://doi.org/10.1186/ s40168-015-0071-z.

98. Matsuki T, Yahagi K, Mori H, Matsumoto H, Hara T, Tajima S, Ogawa E, Kodama H, Yamamoto K, Yamada T, Matsumoto S, Kurokawa K. A key genetic factor for fucosyllactose utilization affects infant gut microbiota development. Nat Commun. 2016;7:11939. https://doi.org/10.1038/ ncomms 11939

99. Vatanen T, Franzosa EA, Schwager R, Tripathi S, Arthur TD, Vehik K, Lernmark A, Hagopian WA, Rewers MJ, She JX, Toppari J, Ziegler AG, Akolkar B, Krischer JP, Stewart CJ, Ajami NJ, Petrosino JF, Gevers D, Lahdesmaki $\mathrm{H}$, Vlamakis $\mathrm{H}$, Huttenhower $\mathrm{C}$, Xavier RJ. The human gut microbiome in early-onset type 1 diabetes from the TEDDY study. Nature. 2018;562(7728):589-94. https://doi.org/10.1038/s41586-018-0620-2.

100. Stewart CJ, Ajami NJ, O'Brien JL, Hutchinson DS, Smith DP, Wong MC, Ross MC, Lloyd RE, Doddapaneni H, Metcalf GA, Muzny D, Gibbs RA, Vatanen T, Huttenhower C, Xavier RJ, Rewers M, Hagopian W, Toppari J, Ziegler AG, She JX, Akolkar B, Lernmark A, Hyoty H, Vehik K, Krischer $J P$, Petrosino JF. Temporal development of the gut microbiome in early childhood from the TEDDY study. Nature. 2018;562(7728):583-8. https://doi.org/10.1038/s41586-018-0617-x.

101. Avershina E, Storro O, Oien T, Johnsen R, Wilson R, Egeland T, Rudi K. Bifidobacterial succession and correlation networks in a large unselected cohort of mothers and their children. Appl Environ Microbiol. 2013;79(2):497-507. https://doi.org/10.1128/AEM.02359-12.
102. Turroni F, Peano C, Pass DA, Foroni E, Severgnini M, Claesson MJ, Kerr C, Hourihane J, Murray D, Fuligni F, Gueimonde M, Margolles A, De Bellis G, O'Toole PW, van Sinderen D, Marchesi JR, Ventura M. Diversity of bifidobacteria within the infant gut microbiota. PLoS ONE. 2012;7(5):e36957. https://doi.org/10.1371/journal.pone.0036957.

103. Odamaki T, Kato K, Sugahara H, Hashikura N, Takahashi S, Xiao JZ, Abe F, Osawa R. Age-related changes in gut microbiota composition from newborn to centenarian: a cross-sectional study. BMC Microbiol. 2016;16:90. https://doi.org/10.1186/s12866-016-0708-5.

104. Kato K, Odamaki T, Mitsuyama E, Sugahara H, Xiao JZ, Osawa R. Age-related changes in the composition of gut bifidobacterium species. Curr Microbiol. 2017;74(8):987-95. https://doi.org/10.1007/ s00284-017-1272-4.

105. Davis JC, Totten SM, Huang JO, Nagshbandi S, Kirmiz N, Garrido DA, Lewis ZT, Wu LD, Smilowitz JT, German JB, Mills DA, Lebrilla CB. Identification of Oligosaccharides in Feces of Breast-fed Infants and Their Correlation with the Gut Microbial Community. Mol Cell Proteomics. 2016;15(9):2987-3002. https://doi.org/10.1074/mcp.M1 16.060665.

106. Ward RE, Ninonuevo M, Mills DA, Lebrilla CB, German JB. In vitro fermentation of breast milk oligosaccharides by Bifidobacterium infantis and Lactobacillus gasseri. Appl Environ Microbiol. 2006;72(6):4497-9. https://doi.org/10.1128/AEM.02515-05.

107. Garrido D, Ruiz-Moyano S, Kirmiz N, Davis JC, Totten SM, Lemay DG, Ugalde JA, German JB, Lebrilla CB, Mills DA. A novel gene cluster allows preferential utilization of fucosylated milk oligosaccharides in Bifidobacterium longum subsp. longum SC596. Sci Rep. 2016;6:35045. https://doi. org/10.1038/srep35045.

108. Ruiz-Moyano S, Totten SM, Garrido DA, Smilowitz JT, German JB, Lebrilla $\mathrm{CB}$, Mills DA. Variation in consumption of human milk oligosaccharides by infant gut-associated strains of Bifidobacterium breve. Appl Environ Microbiol. 2013;79(19):6040-9. https://doi.org/10.1128/AEM.01843-13.

109. Garrido D, Dallas DC, Mills DA. Consumption of human milk glycoconjugates by infant-associated bifidobacteria: mechanisms and implications. Microbiology (Reading). 2013;159(Pt 4):649-64. https://doi.org/ 10.1099/mic.0.064113-0.

110. Sela DA, Garrido D, Lerno L, Wu S, Tan K, Eom HJ, Joachimiak A, Lebrilla CB, Mills DA. Bifidobacterium longum subsp. infantis ATCC 15697 alphafucosidases are active on fucosylated human milk oligosaccharides. Appl Environ Microbiol. 2012;78(3):795-803. https://doi.org/10.1128/ AEM.06762-11.

111. Garrido D, Kim JH, German JB, Raybould HE, Mills DA. Oligosaccharide binding proteins from Bifidobacterium longum subsp. infantis reveal a preference for host glycans. PLoS ONE. 2011;6(3):e17315. https://doi. org/10.1371/journal.pone.0017315.

112. Pichler MJ, Yamada C, Shuoker B, Alvarez-Silva C, Gotoh A, Leth ML, Schoof E, Katoh T, Sakanaka M, Katayama T, Jin C, Karlsson NG, Arumugam M, Fushinobu S, Abou Hachem M. Butyrate producing colonic Clostridiales metabolise human milk oligosaccharides and cross feed on mucin via conserved pathways. Nat Commun. 2020;11(1):3285. https://doi.org/10.1038/s41467-020-17075-x.

113. Wu H, Rebello O, Crost EH, Owen CD, Walpole S, Bennati-Granier C, Ndeh D, Monaco S, Hicks T, Colvile A, Urbanowicz PA, Walsh MA, Angulo J, Spencer DIR, Juge N. Fucosidases from the human gut symbiont Ruminococcus gnavus. Cell Mol Life Sci. 2020. https://doi.org/10.1007/ s00018-020-03514-x.

114. Yoshida E, Sakurama H, Kiyohara M, Nakajima M, Kitaoka M, Ashida H, Hirose J, Katayama T, Yamamoto K, Kumagai H. Bifidobacterium longum subsp. infantis uses two different beta-galactosidases for selectively degrading type-1 and type-2 human milk oligosaccharides. Glycobiology. 2012;22(3):361-8. https://doi.org/10.1093/glycob/cwr116.

115. Zuniga M, Monedero V, Yebra MJ. Utilization of host-derived glycans by intestinal Lactobacillus and Bifidobacterium species. Front Microbiol. 1917;2018:9. https://doi.org/10.3389/fmicb.2018.01917.

116. Borewicz K, Gu F, Saccenti E, Arts ICW, Penders J, Thiijs C, van Leeuwen SS, Lindner C, Nauta A, van Leusen E, Schols HA, Smidt H. Correlating infant faecal microbiota composition and human milk oligosaccharide consumption by microbiota of one-month old breastfed infants. Mol Nutr Food Res. 2019. https://doi.org/10.1002/mnfr.201801214.

117. Yu ZT, Nanthakumar NN, Newburg DS. The human milk oligosaccharide 2'-fucosyllactose quenches Campylobacter jejuni-induced inflammation in human epithelial cells HEp-2 and HT-29 and in mouse intestinal 
mucosa. J Nutr. 2016;146(10):1980-90. https://doi.org/10.3945/jn.116. 230706.

118. Manthey CF, Autran CA, Eckmann L, Bode L. Human milk oligosaccharides protect against enteropathogenic Escherichia coli attachment in vitro and EPEC colonization in suckling mice. J Pediatr Gastroenterol Nutr. 2014;58(2):165-8. https://doi.org/10.1097/MPG.0000000000 000172.

119. Chen P, Reiter T, Huang B, Kong N, Weimer BC. Prebiotic oligosaccharides potentiate host protective responses against L. monocytogenes infection. Pathogens. 2017. https://doi.org/10.3390/pathogens6040068.

120. Ackerman DL, Doster RS, Weitkamp JH, Aronoff DM, Gaddy JA, Townsend SD. Human milk oligosaccharides exhibit antimicrobial and antibiofilm properties against Group B Streptococcus. ACS Infect Dis. 2017;3(8):595-605. https://doi.org/10.1021/acsinfecdis.7b00064.

121. Lin AE, Autran CA, Szyszka A, Escajadillo T, Huang M, Godula K, Prudden AR, Boons GJ, Lewis AL, Doran KS, Nizet V, Bode L. Human milk oligosaccharides inhibit growth of group B Streptococcus. J Biol Chem. 2017;292(27):11243-9. https://doi.org/10.1074/jbc.M117.789974.

122. Hanisch FG, Hansman GS, Morozov V, Kunz C, Schroten H. Avidity of alpha-fucose on human milk oligosaccharides and blood groupunrelated oligo/polyfucoses is essential for potent norovirus-binding targets. J Biol Chem. 2018;293(30):11955-65. https://doi.org/10.1074/ jbc.RA117.001369.

123. Koromyslova A, Tripathi S, Morozov V, Schroten H, Hansman GS. Human norovirus inhibition by a human milk oligosaccharide. Virology. 2017;508:81-9. https://doi.org/10.1016/j.virol.2017.04.032.

124. Laucirica DR, Triantis V, Schoemaker R, Estes MK, Ramani S. Milk oligosaccharides inhibit human rotavirus infectivity in MA104 cells. J Nutr. 2017;147(9):1709-14. https://doi.org/10.3945/jn.116.246090.

125. Xiao L, Van't Land B, Engen PA, Naqib A, Green SJ, Nato A, LeusinkMuis T, Garssen J, Keshavarzian A, Stahl B, Folkerts G. Human milk oligosaccharides protect against the development of autoimmune diabetes in NOD-mice. Sci Rep. 2018;8(1):3829. https://doi.org/10.1038/ s41598-018-22052-y.

126. Thompson AJ, de Vries RP, Paulson JC. Virus recognition of glycan receptors. Curr Opin Virol. 2019;34:117-29. https://doi.org/10.1016/j.coviro. 2019.01.004.

127. Jantscher-Krenn E, Lauwaet T, Bliss LA, Reed SL, Gillin FD, Bode L. Human milk oligosaccharides reduce Entamoeba histolytica attachment and cytotoxicity in vitro. Br J Nutr. 2012;108(10):1839-46. https://doi. org/10.1017/S0007114511007392.

128. Gonia S, Tuepker M, Heisel T, Autran C, Bode L, Gale CA. Human milk oligosaccharides inhibit Candida albicans invasion of human premature intestinal epithelial cells. J Nutr. 2015;145(9):1992-8. https://doi.org/10. 3945/jn.115.214940.

129. Hillman ET, Lu H, Yao T, Nakatsu CH. Microbial ecology along the gastrointestinal tract. Microbes Environ. 2017;32(4):300-13. https://doi.org/10. 1264/jsme2.ME17017.

130. Engfer MB, Stahl B, Finke B, Sawatzki G, Daniel H. Human milk oligosaccharides are resistant to enzymatic hydrolysis in the upper gastrointestinal tract. Am J Clin Nutr. 2000;71(6):1589-96. https://doi.org/10.1093/ ajen/71.6.1589.

131. German JB, Freeman SL, Lebrilla CB, Mills DA. Human milk oligosaccharides: evolution, structures and bioselectivity as substrates for intestinal bacteria. Nestle Nutr Workshop Ser Pediatr Program. 2008;62:205-18. https://doi.org/10.1159/000146322 (discussion 218-22).

132. van den Elsen LWJ, Garssen J, Burcelin R, Verhasselt V. Shaping the gut microbiota by breastfeeding: the gateway to allergy prevention?. Front Pediatr. 2019;7:47. https://doi.org/10.3389/fped.2019.00047.

133. Jost T, Lacroix C, Braegger C, Chassard C. Impact of human milk bacteria and oligosaccharides on neonatal gut microbiota establishment and gut health. Nutr Rev. 2015;73(7):426-37. https://doi.org/10.1093/nutrit/ nuu016.

134. Hao H, Zhu L, Faden HS. The milk-based diet of infancy and the gut microbiome. Gastroenterol Rep. 2019;7(4):246-9. https://doi.org/10. 1093/gastro/goz031.

135. James K, O'Connell Motherway M, Penno C, O'Brien RL, van Sinderen D. Bifidobacterium breve UCC2003 employs multiple transcriptional regulators to control metabolism of particular human milk oligosaccharides. Appl Environ Microbiol. 2018. https://doi.org/10.1128/AEM.02774-17.
136. Bottacini F, Ventura M, van Sinderen D, O'Connell Motherway M. Diversity, ecology and intestinal function of bifidobacteria. Microb Cell Fact. 2014;13(Suppl 1):S4. https://doi.org/10.1186/1475-2859-13-S1-S4.

137. Gotoh A, Katoh T, Sakanaka M, Ling Y, Yamada C, Asakuma S, Urashima T, Tomabechi Y, Katayama-Ikegami A, Kurihara S, Yamamoto K, Harata G, He F, Hirose J, Kitaoka M, Okuda S, Katayama T. Sharing of human milk oligosaccharides degradants within bifidobacterial communities in faecal cultures supplemented with Bifidobacterium bifidum. Sci Rep. 2018:8(1):13958. https://doi.org/10.1038/s41598-018-32080-3.

138. Asakuma S, Hatakeyama E, Urashima T, Yoshida E, Katayama T, Yamamoto K, Kumagai H, Ashida H, Hirose J, Kitaoka M. Physiology of consumption of human milk oligosaccharides by infant gut-associated bifidobacteria. J Biol Chem. 2011;286(40):34583-92. https://doi.org/10. 1074/jbc.M111.248138.

139. Ploger S, Stumpff F, Penner GB, Schulzke JD, Gabel G, Martens H, Shen Z, Gunzel D, Aschenbach JR. Microbial butyrate and its role for barrier function in the gastrointestinal tract. Ann NY Acad Sci. 2012;1258:52-9. https://doi.org/10.1111/j.1749-6632.2012.06553.x.

140. Reichardt N, Duncan SH, Young P, Belenguer A, McWilliam Leitch C, Scott KP, Flint HJ, Louis P. Phylogenetic distribution of three pathways for propionate production within the human gut microbiota. ISME J. 2014;8(6):1323-35. https://doi.org/10.1038/ismej.2014.14.

141. Schwab C, Ruscheweyh HJ, Bunesova V, Pham VT, Beerenwinkel N, Lacroix C. Trophic interactions of infant bifidobacteria and Eubacterium hallii during L-fucose and fucosyllactose degradation. Front Microbiol. 2017:8:95. https://doi.org/10.3389/fmicb.2017.00095.

142. Yu ZT, Chen C, Newburg DS. Utilization of major fucosylated and sialylated human milk oligosaccharides by isolated human gut microbes. Glycobiology. 2013;23(11):1281-92. https://doi.org/10.1093/glycob/ cwt065.

143. Bidart GN, Rodriguez-Diaz J, Monedero V, Yebra MJ. A unique gene cluster for the utilization of the mucosal and human milk-associated glycans galacto-N-biose and lacto-N-biose in Lactobacillus casei. Mol Microbiol. 2014;93(3):521-38. https://doi.org/10.1111/mmi.12678.

144. Walsh C, Lane JA, van Sinderen D, Hickey RM. Human milk oligosaccharides: shaping the infant gut microbiota and supporting health. J Funct Foods. 2020;72:104074. https://doi.org/10.1016/j.jff.2020.104074.

145. Rudloff S, Pohlentz G, Borsch C, Lentze MJ, Kunz C. Urinary excretion of in vivo (1)(3)C-labelled milk oligosaccharides in breastfed infants. Br J Nutr. 2012;107(7):957-63. https://doi.org/10.1017/S0007114511004016.

146. Wettschureck N, Offermanns S. Mammalian G proteins and their cell type specific functions. Physiol Rev. 2005;85(4):1159-204. https://doi. org/10.1152/physrev.00003.2005.

147. Foata F, Sprenger N, Rochat F, Damak S. Activation of the G-protein coupled receptor GPR35 by human milk oligosaccharides through different pathways. Sci Rep. 2020;10(1):16117. https://doi.org/10.1038/ s41598-020-73008-0.

148. Costerton JW, Irvin RT, Cheng KJ. The bacterial glycocalyx in nature and disease. Annu Rev Microbiol. 1981;35:299-324. https://doi.org/10.1146/ annurev.mi.35.100181.001503.

149. Morrow AL, Ruiz-Palacios GM, Altaye M, Jiang X, Guerrero ML, MeinzenDerr JK, Farkas T, Chaturvedi P, Pickering LK, Newburg DS. Human milk oligosaccharides are associated with protection against diarrhea in breast-fed infants. J Pediatr. 2004;145(3):297-303. https://doi.org/10. 1016/j.jpeds.2004.04.054.

150. Liu L, Johnson HL, Cousens S, Perin J, Scott S, Lawn JE, Rudan I, Campbell H, Cibulskis R, Li M, Mathers C, Black RE. WHO Child Health Epidemiology Reference Group of Unicef. Global, regional, and national causes of child mortality: an updated systematic analysis for 2010 with time trends since 2000. Lancet. 2012;379(9832):2151-61. https://doi. org/10.1016/S0140-6736(12)60560-1.

151. Ruiz-Palacios GM, Cervantes LE, Ramos P, Chavez-Munguia B, Newburg DS. Campylobacter jejuni binds intestinal $\mathrm{H}(\mathrm{O})$ antigen (Fuc alpha 1, 2Gal beta 1, 4GIcNAc), and fucosyloligosaccharides of human milk inhibit its binding and infection. J Biol Chem. 2003;278(16):14112-20. https://doi. org/10.1074/jbc.M207744200

152. He Y, Liu S, Kling DE, Leone S, Lawlor NT, Huang Y, Feinberg SB, Hill DR, Newburg DS. The human milk oligosaccharide 2'-fucosyllactose modulates CD14 expression in human enterocytes, thereby attenuating LPS-induced inflammation. Gut. 2016;65(1):33-46. https://doi.org/ 10.1136/gutjnl-2014-307544. 
153. Lin AE, Autran CA, Espanola SD, Bode L, Nizet V. Human milk oligosaccharides protect bladder epithelial cells against uropathogenic Escherichia coli invasion and cytotoxicity. J Infect Dis. 2014;209(3):389-98. https://doi.org/10.1093/infdis/jit464.

154. Andreas NJ, Al-Khalidi A, Jaiteh M, Clarke E, Hyde MJ, Modi N, Holmes E, Kampmann B, Le Mehring Doare K. Role of human milk oligosaccharides in Group B Streptococcus colonisation. Clin Transl Immunol. 2016;5(8):e99. https://doi.org/10.1038/cti.2016.43.

155. Ramani S, Stewart CJ, Laucirica DR, Ajami NJ, Robertson B, Autran CA Shinge D, Rani S, Anandan S, Hu L, Ferreon JC, Kuruvilla KA, Petrosino JF, Venkataram Prasad BV, Bode L, Kang G, Estes MK. Human milk oligosaccharides, milk microbiome and infant gut microbiome modulate neonatal rotavirus infection. Nat Commun. 2018;9(1):5010. https://doi. org/10.1038/s41467-018-07476-4.

156. Li M, Monaco MH, Wang M, Comstock SS, Kuhlenschmidt TB, Fahey GC Jr, Miller MJ, Kuhlenschmidt MS, Donovan SM. Human milk oligosaccharides shorten rotavirus-induced diarrhea and modulate piglet mucosal immunity and colonic microbiota. ISME J. 2014;8(8):1609-20. https:// doi.org/10.1038/ismej.2014.10.

157. Comstock SS, Li M, Wang M, Monaco MH, Kuhlenschmidt TB, Kuhlenschmidt MS, Donovan SM. Dietary human milk oligosaccharides but not prebiotic oligosaccharides increase circulating natural killer cell and mesenteric lymph node memory $T$ cell populations in noninfected and rotavirus-infected neonatal piglets. J Nutr. 2017;147(6):1041-7. https:// doi.org/10.3945/jn.116.243774.

158. Ravn V, Dabelsteen E. Tissue distribution of histo-blood group antigens. APMIS. 2000;108(1):1-28. https://doi.org/10.1034/j.1600-0463.2000. d01-1.x.

159. Huang $P$, Morrow $A L$, Jiang $X$. The carbohydrate moiety and high molecular weight carrier of histo-blood group antigens are both required for norovirus-receptor recognition. Glycoconj J. 2009;26(8):1085-96. https://doi.org/10.1007/s10719-009-9229-x.

160. Weichert S, Jennewein S, Hufner E, Weiss C, Borkowski J, Putze J, Schroten $\mathrm{H}$. Bioengineered 2'-fucosyllactose and 3-fucosyllactose inhibit the adhesion of Pseudomonas aeruginosa and enteric pathogens to human intestinal and respiratory cell lines. Nutr Res. 2013;33(10):8318. https://doi.org/10.1016/j.nutres.2013.07.009.

161. Zevgiti S, Zabala JG, Darji A, Dietrich U, Panou-Pomonis E, SakarellosDaitsiotis M. Sialic acid and sialyl-lactose glyco-conjugates: design, synthesis and binding assays to lectins and swine influenza H1N1 virus. J Pept Sci. 2012;18(1):52-8. https://doi.org/10.1002/psc.1415.

162. Duska-McEwen G, Senft AP, Ruetschilling TL, Barrett EG, Buck RH. Human milk oligosaccharides enhance innate immunity to respiratory syncytial virus and influenza in vitro. Food Nutr Sci. 2014;5(14):1387-98.

163. Shirley DT, Farr L, Watanabe K, Moonah S. A review of the global burden, new diagnostics, and current therapeutics for Amebiasis. Open Forum Infect Dis. 2018;5(7):ofy161. https://doi.org/10.1093/ofid/ofy161.

164. Greenberg RG, Benjamin DK Jr. Neonatal candidiasis: diagnosis, prevention, and treatment. J Infect. 2014;69(Suppl 1):S19-22. https://doi.org/ 10.1016/j.jinf.2014.07.012.

165. Maldonado-Contreras AL, McCormick BA. Intestinal epithelial cells and their role in innate mucosal immunity. Cell Tissue Res. 2011;343(1):5-12. https://doi.org/10.1007/s00441-010-1082-5.

166. Pearce SC, Al-Jawadi A, Kishida K, Yu S, Hu M, Fritzky LF, Edelblum KL, Gao N, Ferraris RP. Marked differences in tight junction composition and macromolecular permeability among different intestinal cell types. BMC Biol. 2018;16(1):19. https://doi.org/10.1186/s12915-018-0481-z.

167. Holscher HD, Davis SR, Tappenden KA. Human milk oligosaccharides influence maturation of human intestinal Caco-2Bbe and HT-29 cell lines. J Nutr. 2014;144(5):586-91. https://doi.org/10.3945/jn.113.189704.

168. Holscher HD, Bode L, Tappenden KA. Human milk oligosaccharides influence intestinal epithelial cell maturation in vitro. J Pediatr Gastroenterol Nutr. 2017;64(2):296-301. https://doi.org/10.1097/MPG.00000 00000001274

169. Wu RY, Li B, Koike Y, Maattanen P, Miyake H, Cadete M, Johnson-Henry KC, Botts SR, Lee C, Abrahamsson TR, Landberg E, Pierro A, Sherman PM. Human milk oligosaccharides increase mucin expression in experimental necrotizing enterocolitis. Mol Nutr Food Res. 2019;63(3):e1800658. https://doi.org/10.1002/mnfr.201800658.

170. Belmiro CL, Souza HS, Elia CC, Castelo-Branco MT, Silva FR, Machado $\mathrm{RL}$, Pavao MS. Biochemical and immunohistochemical analysis of glycosaminoglycans in inflamed and non-inflamed intestinal mucosa of patients with Crohn's disease. Int J Colorectal Dis. 2005;20(4):295-304. https://doi.org/10.1007/s00384-004-0677-2.

171. Kong C, Elderman M, Cheng L, de Haan BJ, Nauta A, de Vos P. Modulation of intestinal epithelial glycocalyx development by human milk oligosaccharides and non-digestible carbohydrates. Mol Nutr Food Res. 2019;63(17):e1900303. https://doi.org/10.1002/mnfr.201900303.

172. Lenoir D, Ruggiero-Lopez D, Louisot P, Biol MC. Developmental changes in intestinal glycosylation: nutrition-dependent multi-factor regulation of the fucosylation pathway at weaning time. Biochim Biophys Acta. 1995;1234(1):29-36. https://doi.org/10.1016/0005-2736(94)00254-m.

173. Kavanaugh D, O'Callaghan J, Kilcoyne M, Kane M, Joshi L, Hickey RM. The intestinal glycome and its modulation by diet and nutrition. Nutr Rev. 2015;73(6):359-75. https://doi.org/10.1093/nutrit/nuu019.

174. Angeloni S, Ridet JL, Kusy N, Gao H, Crevoisier F, Guinchard S, Kochhar $\mathrm{S}$, Sigrist $\mathrm{H}$, Sprenger N. Glycoprofiling with micro-arrays of glycoconjugates and lectins. Glycobiology. 2005;15(1):31-41. https://doi.org/10. 1093/glycob/cwh143.

175. Chichlowski M, De Lartigue G, German JB, Raybould HE, Mills DA. Bifidobacteria isolated from infants and cultured on human milk oligosaccharides affect intestinal epithelial function. J Pediatr Gastroenterol Nutr. 2012:55(3):321-7. https://doi.org/10.1097/MPG.0b013e31824fb899.

176. Lewis ED, Richard C, Larsen BM, Field CJ. The importance of human milk for immunity in preterm infants. Clin Perinatol. 2017;44(1):23-47. https://doi.org/10.1016/j.clp.2016.11.008.

177. Guo S, Gillingham T, Guo Y, Meng D, Zhu W, Walker WA, Ganguli K. Secretions of Bifidobacterium infantis and Lactobacillus acidophilus protect intestinal epithelial barrier function. J Pediatr Gastroenterol Nutr. 2017;64(3):404-12. https://doi.org/10.1097/MPG.0000000000001310.

178. Wejryd E, Marti M, Marchini G, Werme A, Jonsson B, Landberg E, Abrahamsson TR. Low diversity of human milk oligosaccharides is associated with necrotising Enterocolitis in extremely low birth weight infants. Nutrients. 2018. https://doi.org/10.3390/nu10101556.

179. Marriage BJ, Buck RH, Goehring KC, Oliver JS, Williams JA. Infants fed a lower calorie formula with 2'FL show growth and 2'FL uptake like breast-fed infants. J Pediatr Gastroenterol Nutr. 2015;61(6):649-58. https://doi.org/10.1097/MPG.0000000000000889.

180. Puccio G, Alliet P, Cajozzo C, Janssens E, Corsello G, Sprenger N, Wernimont S, Egli D, Gosoniu L, Steenhout P. Effects of infant formula with human milk oligosaccharides on growth and morbidity: a randomized multicenter trial. J Pediatr Gastroenterol Nutr. 2017;64(4):624-31. https://doi.org/10.1097/MPG.0000000000001520.

181. Austin S, Cuany D, Michaud J, Diehl B, Casado B. Determination of 2'-fucosyllactose and lacto-N-neotetraose in infant formula. Molecules. 2018. https://doi.org/10.3390/molecules23102650.

182. Goehring KC, Marriage BJ, Oliver JS, Wilder JA, Barrett EG, Buck RH. Similar to those who are breastfed, infants fed a formula containing 2'-fucosyllactose have lower inflammatory cytokines in a randomized controlled trial. J Nutr. 2016;146(12):2559-66. https://doi.org/10.3945/ jn.116.236919.

183. Berger B, Porta N, Foata F, Grathwohl D, Delley M, Moine D, Charpagne A, Siegwald L, Descombes P, Alliet P, Puccio G, Steenhout P, Mercenier A, Sprenger N. Linking human milk oligosaccharides, infant fecal community types, and later risk to require antibiotics. mBio. 2020. https:// doi.org/10.1128/mBio.03196-19.

184. Castillo-Courtade L, Han S, Lee S, Mian FM, Buck R, Forsythe P. Attenuation of food allergy symptoms following treatment with human milk oligosaccharides in a mouse model. Allergy. 2015;70(9):1091-102. https://doi.org/10.1111/all.12650.

185. Sprenger N, Odenwald H, Kukkonen AK, Kuitunen M, Savilahti E, Kunz C. FUT2-dependent breast milk oligosaccharides and allergy at 2 and 5 years of age in infants with high hereditary allergy risk. Eur J Nutr. 2017;56(3):1293-301. https://doi.org/10.1007/s00394-016-1180-6.

186. Kurakevich E, Hennet T, Hausmann M, Rogler G, Borsig L. Milk oligosaccharide sialyl(alpha2,3)lactose activates intestinal CD11c+ cells through TLR4. Proc Natl Acad Sci U S A. 2013;110(43):17444-9. https://doi.org/ 10.1073/pnas.1306322110.

187. Autran CA, Kellman BP, Kim JH, Asztalos E, Blood AB, Spence ECH, Patel AL, Hou J, Lewis NE, Bode L. Human milk oligosaccharide composition predicts risk of necrotising enterocolitis in preterm infants. Gut. 2018;67(6):1064-70. https://doi.org/10.1136/gutjnl-2016-312819. 
188. Vazquez E, Barranco A, Ramirez M, Gruart A, Delgado-Garcia JM, Martinez-Lara E, Blanco S, Martin MJ, Castanys E, Buck R, Prieto P, Rueda R. Effects of a human milk oligosaccharide, 2'-fucosyllactose, on hippocampal long-term potentiation and learning capabilities in rodents. J Nutr Biochem. 2015;26(5):455-65. https://doi.org/10.1016/j.jnutbio. 2014.11.016.

189. Tarr AJ, Galley JD, Fisher SE, Chichlowski M, Berg BM, Bailey MT. The prebiotics 3'Sialyllactose and 6'Sialyllactose diminish stressor-induced anxiety-like behavior and colonic microbiota alterations: Evidence for effects on the gut-brain axis. Brain Behav Immun. 2015;50:166-77. https://doi.org/10.1016/j.bbi.2015.06.025.

190. Elison E, Vigsnaes LK, Rindom Krogsgaard L, Rasmussen J, Sorensen N, McConnell B, Hennet T, Sommer MO, Bytzer P. Oral supplementation of healthy adults with 2'-O-fucosyllactose and lacto-N-neotetraose is well tolerated and shifts the intestinal microbiota. Br J Nutr. 2016;1 16(8):1356-68. https://doi.org/10.1017/S0007114516003354.

191. Suligoj T, Vigsnaes LK, Abbeele PVD, Apostolou A, Karalis K, Savva GM, McConnell B, Juge N. Effects of human milk oligosaccharides on the adult gut microbiota and barrier function. Nutrients. 2020. https://doi. org/10.3390/nu12092808.

\section{Publisher's Note}

Springer Nature remains neutral with regard to jurisdictional claims in published maps and institutional affiliations.
Ready to submit your research? Choose BMC and benefit from:

- fast, convenient online submission

- thorough peer review by experienced researchers in your field

- rapid publication on acceptance

- support for research data, including large and complex data types

- gold Open Access which fosters wider collaboration and increased citations

- maximum visibility for your research: over $100 \mathrm{M}$ website views per year

At BMC, research is always in progress.

Learn more biomedcentral.com/submissions 